IZA DP No. 5674

Young People and the Great Recession

David N.F. Bell

David G. Blanchflower

April 2011 


\title{
Young People and the Great Recession
}

\author{
David N.F. Bell \\ University of Stirling \\ and IZA
}

David G. Blanchflower

Dartmouth College, University of Stirling,

CESifo, NBER and IZA

\section{Discussion Paper No. 5674 \\ April 2011}

IZA

P.O. Box 7240

53072 Bonn

Germany

Phone: +49-228-3894-0

Fax: +49-228-3894-180

E-mail: iza@iza.org

Any opinions expressed here are those of the author(s) and not those of IZA. Research published in this series may include views on policy, but the institute itself takes no institutional policy positions.

The Institute for the Study of Labor (IZA) in Bonn is a local and virtual international research center and a place of communication between science, politics and business. IZA is an independent nonprofit organization supported by Deutsche Post Foundation. The center is associated with the University of Bonn and offers a stimulating research environment through its international network, workshops and conferences, data service, project support, research visits and doctoral program. IZA engages in (i) original and internationally competitive research in all fields of labor economics, (ii) development of policy concepts, and (iii) dissemination of research results and concepts to the interested public.

IZA Discussion Papers often represent preliminary work and are circulated to encourage discussion. Citation of such a paper should account for its provisional character. A revised version may be available directly from the author. 
IZA Discussion Paper No. 5674

April 2011

\section{ABSTRACT}

\section{Young People and the Great Recession}

This article reviews the effects of the Great Recession on youth labour markets. We argue that young people aged 16-24 have suffered disproportionately during the recession. Using the USA and UK as case studies, we analyse youth unemployment using microdata. We argue that there is convincing evidence that the effects of unemployment when young impose costs on individuals and society well into the future. Though the effects of current policies on youth unemployment are uncertain, there is still a strong case for policy intervention to address the difficulties that the young are having in accessing employment.

JEL Classification: J01, J11, J21, J23, J38, J64

Keywords: youth unemployment

Corresponding author:

David Bell

Division of Economics

University of Stirling

Stirling, Scotland

United Kingdom

E-mail: dnfb1@stir.ac.uk 
Youth joblessness has been a problem in many countries for several decades. It has been the subject of a wide range of policy interventions. Yet the accumulated wealth of policy experience failed to prevent a rapid rise in youth unemployment during the so-called "Great Recession" which occurred in 2008-09. This raises serious questions about the relevance of past policy lessons to the present predicament of the youth labour market. Should we discount these past lessons, and what can we learn about future policy from recent experience? These issues are the subject of this paper. We also discuss the longer-term implications of youth unemployment and its effects on the well-being of the young, arguing that our findings reinforce the need to explore policy options that address youth unemployment.

We begin by setting the background context of longer-run trends in youth unemployment. Using evidence across a range of developed countries, we then describe the dynamics of youth unemployment during the Great Recession; next, we look at some micro-econometric evidence on the effects of unemployment from the UK and the USA; finally we take a controversial line on policy, arguing that the conventional wisdom on youth employment policy has turned out to be largely irrelevant during this recession. The solution to the youth unemployment problem is simply put - more jobs for young people.

\section{Policy Background}

Those aged over the minimum school leaving age and less than 25 are generally described as "youth". In 1999, this classification was formalized by the International Labour Office (ILO 2011) in its definitions of the "Key Indicators of the Labour Market” (KILM). One of these, KILM 9, is described as “youth unemployment”. It comprises the number of unemployed that are aged less than 25. The ILO treats those aged 25 and over as "adults", largely because, by that age, most have completed education and have entered the labour force. The lower end of the range, the minimum school-leaving age, varies by country (and by state in the USA). For most OECD countries it lies between 16 and 18. The "youth" age range captures almost all individuals' initial, and potentially formative, experience of the labour market. However, there are still significant contrasts within this age group. Individuals who leave education at the minimum school leaving age are likely to have considerably more work experience by the age of 25 relative to those who spend their late teens and early twenties in full-time education.

Changes in educational participation influence the size of the youth labour market, and therefore youth unemployment rates. Thus, voluntary or mandatory increases in educational participation could potentially increase the youth unemployment rate without any increase in the number of young people seeking work. On the other hand, increased educational participation might have no effect on the youth unemployment rate. This is because many students, particularly part-timers, actively participate in the labour market. In addition, the youth unemployment rate does not include those young people who neither participate in the labour market, nor in education. The so-called NEETs (young people not in education, employment or training) are drawn from both unemployed and inactive youth.

The worsening labour market performance of youth became apparent in the 1970s. Freeman (1979), Welch (1979) and Berger (1984) argued that its genesis lay with the substantial increase in supply associated with the entry of the baby boomers into the 
labour market in the 1970s. But instead of improving as cohort size declined, the relative labour market performance of young people worsened during the 1980s and 1990s. Higher unemployment was accompanied by an increase in the wage gap between adults and youths, particularly during the 1980s and early 1990s. There was some recovery in the late 1990s and the early part of this century, but not to the levels of the early 1970s. As we shall see, there has been a further deterioration of the youth labour market since the beginning of the Great Recession.

There are a number of reasons why youth unemployment rates may be higher than adult rates. In the internal labour market, youths will generally have less specific human capital relevant to the particular firm for whom they work and also less general work skills. Even without a formal last-in first-out (LIFO) policy, firms may take the view that the future benefit of further investment in young workers is outweighed by its current costs. Further, liquidity concerns may cause firms to seek layoffs among younger workers first, particularly where statutory redundancy payments are seniority weighted, as is the case in most countries.

In the external labour market, young workers may be less efficient in job search activities than adults. Younger workers are likely to have fewer contacts and less experience of finding work, placing them at a relative disadvantage compared to adults. They may also find themselves in an experience trap, where employers select workers with experience, and as a result labour market entrants are never hired and so cannot increase their own experience. On the supply side, youths are less likely to have significant financial commitments than their elders. And their parents may be willing to support them should they not find work. Such factors may create an incentive to restrict their job search activity, leading to higher rates of unemployment. Whether the cause is on the demand or the supply side, the outcome is that youths experience considerably higher rates of unemployment than adults.

In response to the substantial increases in youth unemployment during the 1980s and early 1990s, there was a significant increase in policy initiatives targeted at unemployment in general and youth unemployment in particular. These culminated in the OECD Jobs Study (1994), which argued that policies to improve the working of the labour market were critical for reducing high levels of youth unemployment. It suggested that:

"A progressive shift of resources is needed from passive income support to active measures. Active labour market policies improve access to the labour market and jobs; develop job-related skills; and promote more efficient labour markets." (OECD Jobs Study 1994)

With OECD encouragement, many member countries introduced a range of active labour market policies (ALMPs). These were extensively evaluated to determine their labour market effects. In this context, "evaluation” tends to mean comparisons between those "treated" by a particular intervention and a comparable "control” group that are not so "treated". Such evaluations can be described as partial equilibrium in the sense that they focus on a narrow range of outcomes (e.g. difference in the probability of finding full-time employment between the treated and untreated) in distinct sub-populations of the labour force. On the other hand, models that take a 
broader macroeconomic perspective tend to be insufficiently disaggregated to capture the general equilibrium impacts of ALMPs.

Even these partial equilibrium evaluations of ALMP impact have not shown them to be an unqualified success. Heckman and Smith (1999a, 1999b) examined the US Job Training Partnership Act (JTPA), which provided job-training services for economically disadvantaged adults and youth, dislocated workers and those facing significant employment barriers. They found that the estimates of the returns to training were sensitive to a) the set of training centers included in the evaluation b) how outliers in the earnings data are handled c) the construction of the earnings data d) control group substitution d) treatment group drop out. Even after these adjustments they conclude that their results for youth "fit comfortably into the pattern of several decades of research that finds very limited earnings effects for the types of services offered by JTPA". In 1996, when asked by the Economist how much training schemes in the US help their clientele Jim Heckman replied that 'zero is not a bad number' (Economist, 6th April, 1996).

Grubb (1999) is slightly more positive when reviewing US education and training programmes for disadvantaged youths. He argues that successful programmes embody some combination of the following characteristics:

i) close links with the local labour market, targeting jobs with relatively high wages, strong employment growth and opportunities for advancement;

ii) a mix of academic education, occupational skills and on-the-job training;

iii) opportunities to enter further education, to further develop skills and competencies;

iv) support services, focused on the needs of clients and their families; and

v) constant redesign of the programme to learn from past experience.

Auspos et al. (1999) conclude that European ALMPs have not produced earnings gains for participants, but argue that smaller targeted schemes aimed at disadvantaged groups are more effective in raising employment than broad-based training programmes, particularly when used in conjunction with job search interventions. Successful programmes tend to be costly and may be difficult to expand broadly. Bergemann, and van den Berg (2006) argue that training programmes are more effective for women than men in Europe. Focussing on youth, Calmfors et al. (2002) summarize the Swedish experience of ALMPs by arguing that youth programmes have caused substantial displacement effects but the gains for participants are uncertain.

One of the major UK ALMPs is the New Deal for Young People (NDYP). It was established in 1998 and was aimed at those aged 18 to 24. All those in this age group that have been on Job Seekers Allowance (JSA) for more than six months enter the "Gateway" in which they are given extensive advice on how to find employment. Participation is compulsory; every eligible individual who refuses to cooperate faces a loss of entitlement to benefits.

Blundell et al. (2001) show that the NDYP raises the probability of entering employment by around 5 per cent in the short run. Although these effects are relatively small, Van Reenen (2004) calculates that the marginal social benefit of the programme exceeds its marginal social cost. Blundell et al (2004) also found that the 
impact of the program significantly raised transitions to employment by about 5 percent but argue that this effect may fall in the longer run. These positive effects are relatively small. However, this is one of the largest scale ALMPs with more than 2 million people entering employment via NDYP, during its existence.

Card, Kluve and Weber (2009) carry out a meta-analysis of ALMPs. They examine 199 programmes drawn from 97 studies over the period 1995 to 2007. The programmes themselves are heterogeneous covering classroom and work experience, job search assistance, subsidized public and private employment programs. In the short run, the number of programs with a significantly positive outcome only exceeds those with a significantly negative outcome by a small margin. Over longer time horizons, the balance is more in favour of positive outcomes. There are also significant differences between countries in the types of programs, which succeed or fail. There is no upward trend over time in positive outcomes. The evaluations contain little information on costs, making it difficult to establish how affordable large-scale expansion of successful programs might be. The Card et al. study supports Grubb and Martin's (OECD 2001) conclusion that, “one of the most disappointing conclusions from the evaluation literature is that almost all evaluations show that special measures are not effective for disadvantaged youths.”

General conclusions on ALMPS seem to be that:

- Evaluations show that successful programmes, which enhance the probability of finding employment, tend to target particular groups, devoting substantial resources per client and keeping the focus close to the jobs market.

- Many evaluation studies show more favourable outcomes for females than for males.

- Positive ALMP evaluations tended to occur during periods of buoyant labour demand. Problems of deadweight loss increase when there is excess supply of labour.

- The effects of scaling up ALMPs that have positive labour market outcomes are uncertain.

- ALMPs aimed at younger people are less successful than those which target older people.

- Little is known about the general equilibrium effects of ALMPs.

\section{Youth Labour Markets in the Great Recession}

The focus on ALMPs preceded the so-called "Great Recession”, which was associated with the financial collapse of late 2007. Most countries experienced a sharp fall in output beginning in early 2008. The demand for labour fell and unemployment increased. We show below that youth unemployment increased more rapidly than the overall level of unemployment as the recession deepened. We also discuss how many countries introduced discretionary policies to combat the increases in unemployment specifically associated with the Great Recession. These were in addition to the automatic stabilisers which supported income levels as demand fell.

Table 1 contains estimated youth unemployment rates for OECD countries from 1970 to $2009 .{ }^{1}$ From 1970 to 2004, the data are averaged over five-year periods, with more

\footnotetext{
${ }^{1}$ Data drawn from OECD Statistical Extracts: LFS by sex and age.
} 
recent data following in successive columns. Youth unemployment rates have been high throughout this period and have generally increased since the beginning of the recession. In 2009 youth unemployment rates among larger industrial economies included France (22.8\%), Italy(25.4\%), Spain (37.4\%), Sweden (25\%), UK (18.9\%) and USA (17.6\%). For the OECD as a whole it increased from $12 \%$ to $16.7 \%$ over the same period, the highest recorded level since 1970. Only in Japan, Korea, and the Netherlands were youth unemployment rates in single digits at the beginning of 2010 and only Germany experienced a reduction in the rate of youth unemployment between 2007 and 2009.

Most OECD member states had high rates of youth unemployment prior to the Great Recession. But in Sweden and the USA, youth unemployment in 2009 was at a historically high rate. In the UK, it reached levels not experienced since the early 1980s, while in Canada, France and Italy it rose to levels not encountered during the last decade. In most other OECD countries, youth unemployment increased during the recession, but only to levels that were typical of the first half of the decade. One important exception was Germany, where youth unemployment rates in 2009 were below their pre-recession value. Table 1 thus establishes that youth unemployment rates have generally trended upwards between 1970 and 2009, but that particularly rapid increases took place in some countries during 2008 and 2009. Increases in youth unemployment by country have varied widely since the onset of recession.

Unemployment rates increased generally during the recession. Therefore it is reasonable to question whether the young have suffered disproportionately. We have previously argued that young workers are consistently more likely to be unemployed than adults (Bell and Blanchflower, 2009, 2010a, 2011). But one way to establish this statistically is to calculate the ratio of youth to adult unemployment rates. This is a useful measure of whether youth or adults are experiencing greater difficulties in the labour market.

Youth-adult unemployment rate ratios for a number of countries are shown in Table 2. These are drawn from the same OECD data as used in Table 1. For the OECD as a whole, the ratio of youth to adult rates in 2009 reached its highest level since 19751979. At that time, the overall OECD unemployment rate was 4.8 per cent. In 2009, it was 6.9 per cent. Thus, although the youth-adult unemployment ratio was the same in both periods, the OECD youth unemployment rate itself was 20.9 per cent in 2009 compared with 10.4 per cent in 2005-09. The Great Recession was associated with high absolute rates of youth unemployment and high rates relative to adults.

The youth-adult ratio varies considerably between countries, reflecting both institutional and policy differences as well as differences in the demand and supply of labour. The US ratio is relatively low largely because unemployment rates among older workers are relatively high. Youth-adult ratios in some countries, such as Italy, Australia and France, have fallen over time, while in others, such as the UK and Sweden, the young have tended to comprise an increasing share of the unemployed.

Further confirmation with more recent data of the worsening position of youth is shown in Table 3. Drawn from Eurostat data, it shows unemployment rates for youth and adults in 2008 Q1 and 2010 Q4 and the changes in these rates over this interval. The final column shows the difference between the change in the youth rate and the 
change in the adult rate. The countries are ordered by change in the youth unemployment rate between 2008 Q1 and 2010 Q4. Youth unemployment rates have increased most in the Baltic States, Spain, Ireland and Slovakia, Cyprus and Greece. Most of these countries have been affected by construction "bubbles" and/or sovereign debt crises. They also tend to be the countries where the growth in youth unemployment rates has substantially exceeded the growth in adult rates as shown in the final column. At the other end of the spectrum, Germany and Austria, countries which avoided the worst effects of the financial collapse, have actually experienced youth rates growing less than adult rates between 2008 and 2010. But these are very much the exceptions: the general conclusion from Table 3, confirming those of Tables 1 and 2, is that the Great Recession has been associated with much more rapid growth in youth than adult unemployment rates.

To analyse the relationship between youth and adult unemployment rates over time and over countries, we regress the youth unemployment rate on the adult rate including both time and country dummies using the 1970-2009 OECD data that underlies Tables 1 and 2. We include one further right-hand side variable - the ratio of the labour force aged 16-24 to that aged 25-64. This is intended to capture the effects of changes in relative cohort size (and therefore age-specific labour supply) following Freeman (1979). The pattern of time dummies indicates how far individual years differ from the overall relationship between youth and adult rates, while the country dummies indicate which countries are performing better or worse than the international average. This is purely a descriptive analysis, which takes no account of changes in the relative price of youth and adult labour or in their relative marginal products.

Our estimates confirm the cyclical sensitivity of youth unemployment ${ }^{2}$. Youth rates change by $1.79 \%$ for each $1 \%$ change in adult rates. Further, increases in the relative size of the youth labour force are associated with small increases in youth unemployment. The estimates suggest that a $10 \%$ increase in ratio of the youth to adult labour force at its mean value $(28.5 \%)$ is associated with a $0.5 \%$ increase in the youth unemployment rate.

Values of the time and country dummy variables are shown in Figures 1 and 2 respectively. The time dummies show that the major increase in youth rates relative to those of adults took place between 1970 and 1981. A substantial reduction in youth rates relative to adults followed but ended in 1989. From then until 2007 there was a steady upward trend, reflecting more difficult labour market conditions for young people seeking a job. This coincided with a period when unemployment was falling in most OECD labour markets. However, Figure 2 shows that, since the onset of the Great Recession, there was an acceleration of the relative deterioration of youth rates. Thus, in 2009, conditional on adult rates, youth unemployment rates were $8 \%$ above their 1970 value.

\footnotetext{
2 The estimated equation is:

youth rate $=\quad-0.07+1.79$ adult rate +0.20 labour force ratio + time and country dummies

$\mathrm{N}=760, \mathrm{R}^{2}=0.9177$

(40.05) ( $\quad$ ( 5.96$) \quad$-ratios in brackets)
} 
The country dummies reflect differences between youth and adult rates throughout the period. The recent recession will only have a limited impact on them. They show a clear pattern, with Mediterranean countries having significantly higher rates of youth unemployment than most of those in Northern Europe and other parts of the developed world. These differences may reflect rigidities in Mediterranean labour markets, such as high levels of job protection afforded to permanent contract workers in Spain or greater willingness of parents to continue to support children at home in these societies.

To further reinforce the view that youth unemployment during the Great Recession has been relatively high, we present micro-econometric evidence from a different data source. In Table 4 we show how the incidence of unemployment has changed since the start of the Great Recession in the 27 member countries of the European Union. We make use of micro data from three Eurobarometer surveys from February 2008 (\#69.1; \#69.2 and \#70.1) and compare them with the most recent data files available from two surveys from the latter half of 2009 (\#72.1 \& \#72.2) through to February 2010 (\#73.1). For the EU27 the overall unemployment rate was 8.6\% in February 2010 compared with $6.7 \%$ in February 2008. In total we have approximately 88,000 observations.

We use this analysis to highlight a further dimension of the youth unemployment issue - the role of education. As we shall see, unemployment rates tend to be higher among the poorly qualified young. To quantify this effect, we estimate the probability that an individual is unemployed conditional on age, gender, year and education. The sample is set equal to the labour force. Thus, we exclude the inactive young not in education who would tend to further highlight the difficulties of the young. Their exclusion largely stems from the lack of consistent data on this group through time and by country. However, it is worth noting that in England and Wales, for which consistent data are available, the proportion of 16 to 24 year olds not in education, employment or training increased by only 2.5 per cent between 2007 Q4 and 2010 Q4 - much less than the increase in the youth unemployment rate (Source: Department of Education).

Column 1 restricts the sample to 2008. Column 2 pools 2009 and 2010, while the final column pools all time periods. First, it is apparent from the change in the coefficient of the under 25 dummy that the share of unemployment accounted for by the young has risen during the recession. This is confirmed by the significant interaction terms in the final column which shows the incidence of unemployment increasingly falling on the young during this recession, consistent with the OECD data. Second, the more educated are less likely to experience unemployment, and this effect has increased during the recession. This is shown by the increasingly negative coefficient on those who left school at age twenty or above in 2009-10. This is consistent with the unconditional statistics which show that across all age groups, those with higher qualifications experience lower unemployment rates. According to Eurobarometer \#73.1, which surveyed respondents in the EU27 between January and February 2010, the weighted EU27 average unemployment rates by education attainment suggested unemployment rates of $7.2 \%$ for individuals who left school at age 20 or above; $15.2 \%$ for those who left between 16 and 19 and 20.8\% for those who left school earlier. However, these educational differences are measured across all age groups: 
They do not isolate the impact of educational attainment on the unemployment experiences of those aged less than 25 . We return to this issue subsequently.

These analyses of youth unemployment and youth-adult unemployment ratios do not tell the full story of the difficulties face by youth during the recession. Bell and Blanchflower (2010b) establish that in the UK at least, the young are underemployed, in the sense of being more likely to work part-time even though they would prefer full-time and to be in temporary jobs rather than in permanent ones. Those aged under 25 also state a preference to work more hours while older workers would like to reduce their hours. Young people that are out of the labour force are more likely to describe themselves as wishing to have a job than are older inactive people. Even though these effects suggest greater excess supply of labour among the young, they are not captured by the unemployment rate.

Another key influence on recorded unemployment is participation. For younger age groups, participation rates were negatively correlated with unemployment rates during the Great Recession, suggesting a discouraged worker effect. Using the same OECD labour market data as previously, a simple regression of changes in participation rates between 2007 and 2009 for those aged 16-24 on changes in unemployment rates for the same age group yielded a coefficient of -0.65 , significant at the $5 \%$ level. Thus, the increase in youth unemployment has been accompanied by a decline in participation. One symptom of this is the increase in applications for tertiary education from young people. Although students may still take part-time work and thus not drop out of the labour market completely, the reduction in the opportunity cost of study makes investment in human capital more attractive. In both the UK and the USA, college applications increased significantly during 2010. This is consistent with the evidence of Clark (forthcoming) that student enrolment rises during recessions.

Another influence on recorded youth unemployment is migration, which tends to be concentrated among the young. Ireland and Spain experienced reductions in participation much lower than predicted by our estimated relationship between changes in unemployment and changes in participation. The reduction in participation in Ireland may have been attenuated by emigration. In 2009, Ireland experienced its first net emigration since 1995 (Central Statistics Office Ireland, 2010). During 2009, after the onset of recession, net migration from Ireland of those in the 15-24 age group exceeded total net migration - there was still net immigration in other age groups. Thus, age-selective emigration may have reduced the youth-adult unemployment ratio in Ireland. The recession also had a dramatic effect on flows of migrants into and out of Spain. In 2008 and 2009, the number of workers in Spain on permanent contracts declined by 52,000, while the number on permanent contracts fell by 1.33 million3. Scarpetta et al (2010) argue that many of those on temporary contracts were either migrants or young people:

"The incidence of temporary contracts differs a lot across countries. At least half of all young workers have a temporary contract in Poland, Spain,

3

http://extranjeros.mtas.es/es/ObservatorioPermanenteInmigracion/Publicaciones/archivos/Inmigracion_ _Mercado_de_Trabajo_OPI25.pdf 
Sweden, Portugal, France, Germany and Switzerland. But this proportion falls to $20 \%$ or less in Hungary, the Czech Republic, the Slovak Republic, Turkey and the United Kingdom."

As mentioned above, there are also important contrasts between the young. For example, in the USA, the increase in youth unemployment has been particularly concentrated among young men. Data from the Bureau of Labor Statistics show that the unemployment rate for males aged 16 to 24 increased from 12.7\% in 2008Q1 to $22.0 \%$ in 2009Q4: for females the equivalent increase was only from $10.2 \%$ to $15.9 \%$. In the EU, the increase has been more balanced across the sexes, with Eurostat data indicating an increase from $14.6 \%$ to $21.3 \%$ for men aged $16-24$ and from $14.9 \%$ to 20.1\% for women in the same age group between 2008 Q1 and 2010 Q4.

Another important distinction is in educational attainment. Table 5 contains information on changes in youth unemployment by educational qualification in the EU. Three categories of education are defined: those with primary or more secondary qualifications; those with upper secondary or some form of non-tertiary education and those with tertiary level qualifications. Where available, data are shown for 2008 Q1 and 2009 Q3.

It is not clear that during the Great Recession increases in youth unemployment have been concentrated on the poorly educated. In the EU as a whole, rates of unemployment among those with a tertiary education qualification have risen more sharply than have those with primary or secondary qualifications, albeit from a lower base. Thus in Belgium, Italy and a number of eastern European states, unemployment rates among graduates are higher than those with a secondary qualification. One possible explanation is a genuine oversupply of graduates with relatively high reservation wages. An alternative explanation focuses on differences in labour market experience. Within the 16-24 years age group, graduates tend to have less work experience than the poorly qualified. If employers' immediate reaction to a recession is to stop hiring, then graduates may be in a more difficult position than those with lower qualifications, who already have jobs and accumulated experience.

On the demand side of the labour market, it appears that employment opportunities for young workers have been declining more rapidly than those for older employees. Thus, changes in relative demand for labour by age group may partly explain the relative increase in unemployment rates among the young. Table 6 shows how employment by age group changed since the start of the recession. Three age groups are shown: those between 15 and 24; those of prime working age (between 25 and 49) and older workers aged 50 and above. The table shows the percentage change in employment by age group and country for the period 2008 Q1 to 20010 Q3. Data are from Eurostat. Data are sorted by the percentage change in youth employment.

There is a clear contrast in almost all countries between the experience of younger and older workers during the recession. Youth employment has fallen sharply in many countries but in Ireland, the Baltic States, Spain and Portugal the falls in employment all exceed 25 per cent. The experience of older workers has been quite different: in many countries there has been an increase in the employment of older workers. Thus, for example, in Germany, employment among young people fell by $6 \%$, while the employment of workers aged 50 and over increased by 12\%. In Spain, employment of 
the young fell by $32 \%$, of the middle-aged by $10 \%$, but there was a $3 \%$ increase in the employment of older workers. This pattern was replicated in several other countries including the UK, Italy, Poland, Portugal, and Ireland. For the European Union as a whole, employment of youths fell by $8 \%$, prime age workers by $3 \%$, but there has been a $7 \%$ increase in the employment of older workers' employment. Changes in these age-specific employment rates are clearly indicative of substantial age rebalancing in the labour market and form part of the explanation of spiralling youth unemployment rates.

Next, we consider policy responses to the Great Recession, particularly those focused on the labour market. These were mostly put in place during 2008 and 2009. They largely overlaid the ALMP policies already in place and are summarised in OECD (2009). They included measures to stimulate labour demand, to help the unemployed find work and to enhance training. Thus, for example, Germany reduced employee and employer unemployment insurance contribution rates; introduced schemes to subsidise short-time working (STW); increased staffing in the public employment service (PES) and increased funding for training. The Spanish government reduced employers' social contribution for the first two years for new employees; reduced social contributions for young people setting up businesses and extended subsidies for hiring part-time workers; increased PES activity and increased funding for training and vocational education. Sweden deferred two months of employer social security contributions from 2009 to 2011; increased hiring subsidies and made them more widely available; expanded post-school vocational training and realigned highereducation resources with demand. The US government expanded tax credits to employers hiring unemployed veterans or "disconnected" youth (those not employed or education); expanded funding for youth activities with particular emphasis on providing summer job opportunities for young people and projects employing "atrisk" youth; provided grants for training in high-growth and emerging industry sectors and extended the Emergency Unemployment Compensation program which provides additional weeks of benefits.

The UK government established a package for those unemployed for more than six months, which included a recruitment subsidy of $£ 1,000$ for employers who hire those in receipt of JSA for six months or more. It also expanded PES activities. It announced the Young Person's Guarantee at the 2009 Budget with the aim of addressing youth unemployment. It pledged "a guaranteed job, training or work placement for all 18-24 year olds who reach 12 months unemployed to ensure no young people are left behind due to long-term unemployment". In support of this guarantee, the Future Jobs Fund was established with a budget of $£ 1 b n$. It was intended to create up to 100,000 new jobs for young people, and a further 50,000 specifically targeted in areas of high unemployment. Spending on the Future Jobs Fund was reduced by $£ 320 \mathrm{~m}$ as part of the austerity measures introduced by the Coalition Government. The argument was that the provision of temporary jobs through the Young Person" Guarantee was an "ineffective” use of public funds (HM Treasury 2010).

All OECD countries have introduced some labour market measures specifically to combat the adverse effects of the "Great Recession". These cover a wide range of labour market characteristics - wage and non-wage labour costs, labour demand, income support, training and search activity. These vary both in character and in 
scale. Some, but by no means all, are specifically aimed at the particular difficulties faced by young people. Nevertheless, youth unemployment remains at high levels in most OECD countries.

Given the rapidity of the introduction of new labour market policies to combat the recession, levels of displacement and deadweight loss are as yet largely unknown. Unlike the ALMPs discussed previously, these recently introduced measures have not been subject to rigorous evaluation. It is difficult to construct credible counterfactuals and cross-country comparisons may be the only available evidence at present. Yet policies that have improved outcomes in some countries may be less successful in other jurisdictions due to institutional or implementation differences. Nevertheless, there is clearly a need for effective interventions, because as we see in the next section, unemployment has a number of adverse effects particularly for the young.

\section{What Do We Know About Youth Unemployment?}

There is a large literature on youth unemployment, drawing on the experience of recent decades. In this section we draw on this literature in attempting to answer six questions regarding the workings of the youth labour market.

\section{1) Is youth unemployment cyclical or structural?}

Clark and Summers (1982), in their classic study of the dynamics of youth joblessness argue that the problem of teenage unemployment arises from a shortage of jobs. "Aggregate demand has a potent impact on the job prospects and market experience of teenagers" (1982, p.230). Freeman and Wise (1982), for example, found in their study of youth joblessness in the 1970s that it was concentrated, by and large, among a small group who lacked work for extended periods of time. Over half of the male teenage unemployment they examined was among those who were out of work for over six months, a group constituting less than $10 \%$ of the youth labor force and only $7 \%$ of the youth population. Freeman and Wise reported that the youths who make up the relatively small group that was chronically without work had distinctive characteristics. They were disproportionately black; disproportionately high school dropouts, and disproportionately residents of deprived areas.

Blanchflower and Freeman (2000) identified one basic pattern in the job market for young workers: the disproportionately large response of youth employment or unemployment to changes in overall unemployment. They argued that the sensitivity of youth employment and unemployment to the overall rate of unemployment dominate sizable demographic and structural changes favorable to youth in determining how youths fare in the job market. Recently OECD (2008) confirmed this conclusion "Youth unemployment rates are more sensitive to business-cycle conditions than the adult unemployment rate and this high-sensitivity tends to decline progressively with age". Our estimate of the relationship between youth and adult rates in Section 3 indicates that youth unemployment rates change by around 1.79 per cent for every percent change in adult rates, indicating a high degree of cyclical sensitivity.

Consistent with this argument, there is evidence that young people do well in booms. Freeman and Rodgers (2000) analyzed the 1990s boom in the United States and found that it substantially improved the position of non-college educated young men, especially young African Americans who are the most disadvantaged and troubled group in the US. Young men in tight labor markets experienced a substantial boost in 
both employment and earnings. Adult men had no gains and their earnings barely changed even in areas where unemployment rates were below $4 \%$.

There is also evidence of state dependence in youth unemployment. In this context, state dependence means that the experience of one spell of unemployment of itself increases the probability of further spells. This may be because on the demand side, employers are less willing to hire those with a record of unemployment or that, on the supply side, the experience of unemployment discourages individuals from job search activity.

State dependence would imply extended or repeated unemployment spells. These might attenuate the apparent cyclical sensitivity of youth unemployment in aggregate data, leading to the conclusion that youth unemployment is partly structural. And it is clear that some aggregate changes in youth unemployment are not directly linked to cyclical movements. Thus the ILO (2008) noted that recently there had been a declining trend in youth unemployment, suggesting that the world rate of youth unemployment rose from $10.9 \%$ in 1999 to a peak in 2004 of $12.6 \%$ and subsequently declined to 11.9 per cent by 2007. This is not a very large reduction and came at a time when there was a substantial policy effort to combat youth unemployment. This relatively small improvement was swiftly overtaken by events after the onset of recession.

2) How has changed school enrolment impacted on youth unemployment?

Most OECD countries have tried to extend the duration of formal schooling in recent decades. This delays entrance into full-time employment, but not necessarily part-time work. For example, the proportion of the young in the UK in full-time education increased from 26\% in 1993 to 38\% in 2007. Recent OECD data suggests that the proportion of the young who are in school is considerably higher in, for example, Belgium (60\%); Finland (56\%); France (61\%), Italy (57\%); Luxembourg (69\%) and Sweden (57\%). These levels reflect a belief in most industrial countries that greater investment in human capital is required to maintain competitiveness, but they may also reflect lowering costs of education as average family sizes fall. Yet again, it may be a defensive strategy, with enrollment increasing when the labour market deteriorates. For example, in 2010, applications to UK universities increased by 22 per cent over the previous year ${ }^{4}$, reflecting the fall in employment opportunities shown in Table 6.

One effect of increased educational participation is that the 16-24 cohort is now, on average, better qualified than in previous recessions. The UK Labour Force Survey indicates that 5.8 per cent of 16-24 year olds were graduates in 1993, while that share had risen to 13.2 per cent by 2008. The improvement in qualifications is more concentrated among females than males. By 2008, the proportion of females aged 1824 with no qualifications had fallen to 4.6 per cent, but for males was still over 7 per cent. Changes in attainment by gender reflect changes in schooling rates. For example, in the US, the proportion of 16 to 19 year old enrolled in either high school or college increased by $8.9 \%$ between 1979 and 2003. But female enrolment increased by $14.1 \%$, much more rapidly (Congressional Budget Office 2004).

\footnotetext{
${ }^{4}$ See UCAS (UK Universities Admission Service)

http://www.ucas.ac.uk/about_us/media_enquiries/media_releases/2010/080210
} 
Increased schooling affects youth unemployment in two ways. First, so long as increased educational attainment is increasing the "employability" of the young, it should increase the success rate of their job search activity. On the other hand, delayed job market entry caused by additional schooling may reduce the average "employability" of those that are economically active, since those selected into additional schooling are likely to be more able. This effect may be difficult to disentangle within aggregate statistics, since some of those taking additional schooling may also be economically active and therefore classified as either employed or unemployed.

\section{3) Has youth unemployment increased because of competition from migrants?}

One potential cause of increases in youth unemployment is competition from migrants. In the UK, there is some evidence that suggests that the influx of immigrants from the A8 Accession countries from 2004 onward had some negative impact on the employment of the least skilled young people (Blanchflower and Shadforth 2009). But these effects are usually insignificant or when significant, quite small. Card (2009) can find no compelling evidence of a causal impact running from immigration to youth unemployment, though he does argue that competition between unskilled youth and immigrants in the lower tail of the earnings distribution may have increased inequality. There is little empirical support for the notion that increased migration is a root cause of higher rates of youth unemployment. However, these analyses generally precede the Great Recession and as we have seen, net emigration from countries like Ireland and Spain is now keeping youth unemployment rates below what they would otherwise be. These migrant flows comprise both natives and returning immigrants.

\section{4) Are co-habitation decisions influenced by youth unemployment?}

The time when older children leave home is influenced by, and influences, labour market status. Children who remain with their parents gain from intra-household transfers and reduced housing costs. The decision to cohabit is also a form of insurance against unemployment risk. This may affect labour supply decisions. Card and Lemieux (2000) find that when the labour market is performing poorly, the fraction of youth living with parents increases. But, in addition to labour market effects, cohabitation decisions are also significantly impacted, by welfare systems, housing markets and culture (Chiuri and Del Boca 2008). The welfare costs of high youth unemployment may be lower in cultures where there is widespread social acceptance of children staying with their parents well beyond completion of school. In Mediterranean countries cohabitation with adult children is more common than in Northern Europe and this effect may be stronger. This is consistent with our evidence from Section 3 that, ceteris paribus, youth unemployment rates are considerably higher in Mediterranean countries.

5) Have youth wages been too high, so increasing youth unemployment?

Recent movements in the ratio of youth to adult wages in the UK and USA are shown in Figure 3. Both show a secular decline from the early part of this century, some recovery around 2007-2008 followed by further decline during the recession. Employment among older workers has increased during the recession, even though these data suggest that their relative wages have been increasing compared with those of young people in the UK and USA. There is no prima facie evidence of younger 
workers pricing themselves out of jobs. In the UK, this finding is confirmed by analyses of the effect of the minimum wage on employment. A minimum wage was introduced to the UK in 1997 but there is little or no evidence to sustain the argument that it has had an adverse effect on employment (see e.g. Metcalf, 2008). Even if this effect were strong, it would not explain the sudden increase in youth unemployment during this recession.

High levels of unionisation among younger workers might raise their relative pay, but reduce their employment prospects. Unions generally operate rates for the job, which would have the effect of raising the relative wage of the young, making them relatively less attractive to employers. But, although the UK, for example, has relatively high youth unemployment rates, it has especially low union membership rates among the young. Blanchflower (2007) shows, using data from the UK Labour Force Survey, that union density rates for 16-19 year olds in 2004 were $4.3 \%$. In 2007 the union density rate for 16-24 year olds was 9.8\% (Mercer and Notley, 2008, Table 25). It does not appear that youths are pricing themselves out of work, unless their relative productivity is falling especially sharply, but there is no evidence to suggest this.

6) Have young workers been adversely affected by changes in the demand for skills? The changing structure of labour demand may also be adversely affect young people's labour market prospects. A common explanation put forward to support this view is that of skill biased technical change. Technical change increased the skill requirements of production, leaving the unskilled, and particularly the young unskilled, at a significant disadvantage in the labour market (see e.g. Berman et al. 1994).

In the US, it is argued that industrial change has led to a significant change in the demand for skills (Autor, Levy, and Murnane 2003). Rather than additions to labour demand being entirely focused on high-skilled jobs, there has been some increase in demand for low-skilled workers. Many such jobs involve non-routine, or interactive, tasks that cannot be easily automated. In contrast, the demand for skilled workers whose work can be routinised has fallen, mainly due to IT-based automation. In the past, such workers' pay was typically close to the centre of the earnings distribution. The loss of these jobs means that the earnings distribution has been "hollowed out", making the progression from low to high skilled work more difficult. For the poorly educated young, this may mean that there are fewer opportunities to progress from manual work through the various stages to management. However, any such effect is likely to be long-term rather than a direct result of the present recession.

We now discuss the adverse effects of youth unemployment, both at the personal and societal level, arguing that unemployment when young has more negative outcomes than spells of unemployment later in life.

\section{What impact does youth unemployment have?}

There is a wealth of literature showing that unemployment is a stressful life event that directly makes reduces individual wellbeing. This applies not just to the unemployed, but also may affect the employed due to increased anxiety over job security. Unemployment increases susceptibility to malnutrition, illness, mental stress, and loss of self-esteem, and increases the risk of depression. The unemployed also appear to be 
at higher risk of committing suicide, and of poor physical health outcomes later in life. Low levels of happiness and health have predictive power for subsequent outcomes. For example, happy people heal faster, have longer life expectancies, are less likely to get coronary heart disease and, from lab experiments, have higher productivity (Oswald, Proto and Sgroi, 2010) and creativity (Amabile et al, 2005). Knabe and Ratzel (forthcoming) argue that past unemployment affects individuals' future expectations negatively and that it is this insecurity about future prospects that reduces their present well-being. However, drawing the distinction between experienced utility and well-being, Knabe et al.(forthcoming) argue that the unemployed feel sadder than the employed when engaged in similar activities, but can compensate by taking part in more enjoyable activities when the employed are at work.

Youth unemployment also has particularly adverse social impacts. Higher unemployment is associated with increases in burglaries, thefts and drug offences. Unemployment is often part of the cycle where involvement in crime reduces subsequent employment prospects and consequently increases the probability of participating in crime. There is new evidence that even young people who choose to go to college or university are hurt if they enter the labour market during a recession. Kahn (2010) has shown that graduating from college during a recession has large, negative and persistent effects on wages. Lifetime earnings are substantially lower than they would have been if the graduate had entered the labour market in good times. Furthermore, cohorts who graduate in worse national economies tend to end up in lower-level occupations. Giuliano and Spilimbergo (2009) suggest that the period of early adulthood (between 18 and 25) seems to be the age range during which people are more sensitive to macroeconomic conditions. They find that being exposed to a recession before age 17 or after age 25 has no impact on beliefs about life chances. However, youngsters growing up during recessions tend to believe that success in life depends more on luck than on effort; they support more government redistribution, but have less confidence in public institutions. Recessions seem to adversely effect youngsters’ beliefs.

There is also recent evidence on the consequences of rising unemployment on young people from the UK. The Prince's Trust, which was established by the Prince of Wales, conducted three surveys of young people in 2009 and 2010. In comparison with other young people, the young unemployed were significantly more likely to feel ashamed, rejected, lost, anxious, insecure, down and depressed, isolated and unloved. They were also significantly less happy with their health, friendships and family life than those in work or studying, much less confident of the future and more likely to say that they had turned to drugs, that they had nothing to look forward to and that their life had no direction. Many reported having suicidal thoughts (Blanchflower, 2010).

Further, unemployment while young, especially of long duration, appears to be associated with permanent scars rather than the temporary blemishes that result for older workers (Ellwood, 1984). The majority of older workers get over spells of unemployment reasonably quickly while youngsters do not as they struggle to find a toe-hold in the labour market. The scarring effect of youth unemployment has two components: first, for the young, a spell of unemployment does not end with that spell; it raises the probability of being unemployed in later years. Second early spells 
of unemployment also carry a wage penalty. These effects are much larger than for older people experiencing unemployment. Mroz and Savage (2006) find that a six month spell of unemployment at age 22 results in an 8 per cent lower wage at 23 and even at ages 30 and 31, wages are 2-3 per cent lower than they otherwise would have been.

We can now update the evidence on the scarring effects of youth unemployment in the UK. We find new evidence that spells of youth unemployment have harmful impacts on a number of outcomes, such as happiness, health and job satisfaction, many years later. This builds on earlier work by Clark and Oswald (1994) and Winkelmann and Winkelmann (1998) who showed that unemployment lowers happiness.

In order to explore the impact of unemployment while young on subsequent outcomes we examined data from the 1958 birth cohort, the National Child Development Study (NCDS). The NCDS is a continuing longitudinal study that seeks to follow the lives of all those living in Great Britain who were born in one particular week in 1958. To date there have been eight attempts to trace all members of the birth cohort in order to monitor their physical, educational and social development. The first three follow-up sweeps were carried out in 1965, when respondents were aged 7, in 1969 (NCDS1), aged 11 (NCDS2), in 1974, aged 16 (NCDS3). The fourth sweep, NCDS4, was conducted in 1981, when respondents were aged 23. The fifth, sixth and seventh sweeps were carried out at ages 33, 41-42 and 46-47. The latest sweep (NCDS8) was conducted between August 2008 and May 2009, coinciding with the onset of the Great Recession.

We have information from the 1981 sweep on the number of months the respondent had been unemployed between the ages of 16 and 23. This is obtained from reports of the duration of up to four spells of unemployment. Unemployment rates in the UK had risen from $5.4 \%$ in 1979 to $6.8 \%$ in 1980 and $9.6 \%$ in 1981 , when the UK had moved into recession. Unemployment eventually peaked at $11.4 \%$ in the spring of 1984. In the sample, $44.6 \%$ reported that at some time in their working lives they had been unemployed. For those who had been unemployed, the mean number of months they had been unemployed was $7.8(\mathrm{SD}=8.4)$.

We model various measures of wellbeing using responses obtained from NCDS8 when the respondents were age 50. In addition to the controls for region, education and gender, we also include a standard set of controls for well-being equations (Blanchflower and Oswald, 2004a, 2004b 2011). These comprise labour market status, marital status, smoker status and whether the respondent exercises. In addition to the months of unemployment variable we also include an indicator variable on mental health at age 23 measured by the malaise score (indicating a tendency towards depression). For a study using the NCDS Malaise scores at ages 23 and 33, see Cheung and Buchanan (1997). We also include birth weight, obtained at the time of the respondent's birth, and which remarkably impacts life satisfaction half a century later.

The results show that youth unemployment continues to hurt two decades later for the four 2008/9 outcome variables listed above. Interestingly, in all four cases we also included controls for whether the individual was unemployed at age 33 when 
interviewed in NCDS5, but these variables were everywhere insignificant and as they reduced sample sizes were excluded. If the characteristics we seek to model were simply fixed effects that were also associated with unemployment, then one would expect unemployment at age 33 to have a significant explanatory role. Our analysis suggests, however, that spells of unemployment experiences after age 23 have little bearing on later well-being. Our full set of results are reported in Table 7 . We look at the four outcomes in turn.

i) Life satisfaction. Respondents in NCDS8 were asked "On a scale from 0 to 10, where ' 0 ' means that you are completely dissatisfied and '10' means that you are completely satisfied, what number corresponds with how satisfied or dissatisfied you are with the way life has turned out so far?" The mean life satisfaction score was 7.29 and 7.45 if the respondent had not been unemployed at all by age 23 or before and 7.12 if they had. Column 1 reports the results of estimating an ordered logit. Most of the results are standard; life satisfaction is higher for married people, the educated, workers, especially those who work full-time, and those who are not disabled or sick or depressed (a low malaise score at age 23). Those currently unemployed are less happy; there are enduring effects from spells of unemployment while young, which continues to lower happiness more than two decades later. Clark et al (2001) also found, using panel data for Germany from the GSOEP that past unemployment lowers life satisfaction.

In column 1 it is apparent that, as is consistently found in all happiness equations, the current unemployed are less happy. Also, the longer the spell of unemployment before the age of twenty-three, the lower is happiness nearly thirty years later at age 50. Astonishingly, birth weight is positively correlated with happiness many years later even in the presence of all the controls. To our knowledge this finding has not been reported before.

ii) Health status. Respondents in NCDS8 were asked in general would you say your health is - 1 =excellent; $2=$ good; $3=$ fair; $4=$ poor or $5=$ very poor?" Of those who had been unemployed in NCDS4 23.5\% said they were in poor or fair health compared with $14.1 \%$ of those who had not been unemployed. Column 2 of Table 7 estimates an ordered logit with self-reported health as the dependent variable. Once again the youth unemployment variable enters significantly and negative, whereas being unemployed at age 33 did not have a significant impact on health (not reported). The Malaise score is strongly negative also. The currently unemployed are less healthy than full-time employees. The longer the spell of unemployment while young the lower the happiness when they are older. Birth weight is positive and weakly significant.

iii) Respondents were also asked to answer yes or no in answer to the question 'Do you often feel miserable or depressed?' We use this as the dependent variable in Column 3 of Table 7 . Once again spells of unemployment increase depression years later and more so the longer is the spell.

iv) Job satisfaction. Workers were asked for their degree of satisfaction with their current job. Possible answers were "very dissatisfied; somewhat dissatisfied; neither; somewhat satisfied and very satisfied". Column 4 reports the results of estimating an ordered logit. Controls are also included to reflect the degree of job security the 
individual has. Job insecurity lowers job satisfaction (Blanchflower and Oswald, 2011) Youth unemployment lowers job satisfaction whereas middle-age unemployment did not.

People are impacted adversely, in terms of reduced wellbeing, by increases in unemployment. The unemployed themselves lose their jobs and income, but there is a much wider loss of wellbeing. High national unemployment lowers wellbeing especially of the unemployed. It turns out that spells of unemployment are especially harmful to the individual - and to society - when young people become unemployed. A spell of unemployment when young continues to have a negative impact in later life. And the longer the initial spell of unemployment the larger the subsequent negative impact. Clearly any conclusion that such effects will be observed among those young people affected by the current recession is based on the assumption that such effects are not cohort based (i.e. specific to those born in 1958). With this important proviso, our results add to the range of evidence on the negative personal and social impacts of youth unemployment associated with the Great Recession. Our new evidence is consistent with the view that negative impacts on life satisfaction, health and job satisfaction may persist well into the future.

\section{Conclusion}

Unemployment increased in most OECD countries during the Great Recession. But it increased more rapidly among the young. Youth unemployment rates have been increasing relative to adult rates for some time, but the recession increased the size of the gap. Unemployment rates alone do not capture the extent of excess supply in the youth labour market. Other indicators, such as part-time working, working-time preferences and increased migration suggest that younger age groups are more supply-constrained than other age groups by reduced levels of labour demand during the recession. We also know that the age-specific demand for employment has changed significantly in favour of older workers since the onset of the Great Recession. This change has taken place very quickly and therefore is unlikely to be a response to factors that evolve slowly - such as relative wages or technological change. One potential culprit is labour market regulations that make it easier to cut young workers.

Increases in youth unemployment have not been uniform. Some countries, particularly those that have been affected by sovereign debt crises or construction bubbles, such as the Baltic States, Greece, Ireland, Slovakia and Spain have seen very large increases in the rate of youth unemployment. From a longer-run perspective, high rates of youth unemployment in Mediterranean countries may also reflect the greater willingness to insure family members against the adverse consequences of unemployment than in Northern Europe. Countries with large fiscal deficits, such as the UK, are hesitant to increase spending on policies focused on youth, an implicit acknowledgement either that youth unemployment is not thought to be particularly serious or that deficit reduction is more effective in reducing its adverse consequences than policies specifically targeted on youth unemployment.

However, we do know that youth unemployment has adverse effects that extend well beyond the present. Our paper has added to the evidence on these effects, focusing in particular on the delayed negative impacts of unemployment when young on wellbeing, health status and job satisfaction. Hence short-run government savings may be 
at the cost of increased future expenditures associated with the negative effects of youth unemployment and with reduced well-being.

In the aftermath of the recession, OECD Secretary-General Angel Gurría made youth unemployment a key policy priority (OECD 2010). But one of the difficulties facing governments is in knowing which policies are likely to be effective in reducing youth unemployment and do not lead to displacement and deadweight loss. Many policies introduced since 2008 are specific responses to the recession. They are overlaid on a substantial range of Active Labour Market Policies which seek to address specific labour market problems that persisted even though most developed country labour markets were performing quite well during the early part of the last decade. These particularly included measures to improve the access of disadvantaged youth into the labour market. The evaluation literature has given these measures limited support, even though they were largely introduced when labour demand was relatively strong. And although one might expect that the quality of these measures would increase through "learning by doing", the evidence for this is also limited. It is too early to evaluate the effectiveness of the post 2008 measures. Some countries, such as Germany, have managed to contain youth unemployment, while others that have introduced policies not that dissimilar from Germany, have fared much worse. Nevertheless, inaction is not an option when the possible costs of youth unemployment are so high. 


\section{References}

Amabile, T.M., S.G. Barsade, J.S. Mueller, J.S. and B.M. Staw (2005), 'Affect and creativity at work', Administrative Science Quarterly, 50, pp. 367-403.

Autor, D. H, Levy, F. and R.J. Murnane (2003), 'The skill content of recent technological change: an empirical exploration,' Quarterly Journal of Economics, CXVIII, pp. 12791333.

Auspos P, Riccio J and White M (1999), `A review of US and European literature on the microeconomic effects of labour market programmes for young people', Employment Service, Research and Development Report no 20, July 1999, Sheffield: The Employment Service.

Bell, D.G. and D.G. Blanchflower (2009), 'Youth unemployment; déjà vu?', working paper.

Bell, D.N.F and Blanchflower D.G. (2010a), 'Recession and unemployment in the OECD', CESifo Forum, Issue 1, March, pp. 14-22.

Bell, D.N.F and Blanchflower D.G. (2010b), 'UK unemployment in the Great Recession', National Institute Economic Review, October, 214, R3-R25.

Bell, D.N.F and Blanchflower D.G. (2011), 'UK underemployment in the Great Recession', National Institute Economic Review, January, 215, R23-33.

Berger, M.C., (1989) 'Demographic cycles, cohort size, and earnings’, Demography, 26, No 2, May, pp. 311-321

Bergemann, A. and van den Berg, G.J. (2006), 'Active Labor Market Policy effects for women in Europe: a survey’, IZA Discussion Paper 2365

Blanchflower, D.G. (2010), 'The wellbeing of the young', British Journal of Industrial Relations, forthcoming.

Blanchflower, D.G. (2007), 'International patterns of union membership', British Journal of Industrial Relations, March, 45(1), pp. 1-28.

Blanchflower, D.G. and R.B. Freeman, R.B. (1996), 'Growing into work: youth and the labour market over the 1980s and 1990s', OECD Employment Outlook, OECD, Paris

Blanchflower, D.G. and R.B. Freeman, (2000), Youth Employment and Joblessness in Advanced Countries, eds, University of Chicago Press and NBER, Chicago, Illinois.

Blanchflower, D.G. and A.J. Oswald (2011), 'International happiness', Archives in Management Perspectives, forthcoming. 
Blanchflower, D.G., and A.J. Oswald (2004a), 'Well-being over time in Britain and the USA', Journal of Public Economics, 88, pp. 1359-1386.

Blanchflower, D.G., and A.J. Oswald (2004b), 'Money, sex and happiness', $\underline{\text { Scandinavian }}$ Journal of Economics, 106(3), pp. 393-415.

Blanchflower, D.G., and Shadforth, C., (2009), 'Fear, unemployment and migration’. Economic Journal, vol. 119(535), pp. F136-F182.

Blundell , R., Dias, M.C., Meghir , C., Van Reenen, J. (2001) 'Evaluating The Employment Impact Of A Mandatory Job Search Assistance Program', Institute For Fiscal Studies, WP01/20

Blundell, R., Dias, M.C. Meghir, C. and Van Reenen, J. (2004), 'Evaluating the employment impact of a mandatory job search program', Journal of the European Economic Association, June, 2(4), pp. 569-606.

Calmfors, L., Forslund, A. and Hemström, M. (2002), 'Does Active Labour Market Policy work? Lessons from the Swedish Experiences', Institute for International Economic Studies, Stockholm University.

Card, D., (2009) ‘Immigration and Inequality’, NBER Working Paper No. 14683

Card, D., Kluve, J. and Weber, A., (2009) “Active Labor Market Policy Evaluations: A Meta-Analysis”, Economic Journal, 120, F452-F477.

Card D. and T. Lemieux (2000) 'Adapting to circumstance: the evolution of work, school and living arrangements among North American youth', in Blanchflower D. and R. Freeman (eds.) Youth Employment and Joblessness in Advanced Countries, University of Chicago Press and NBER.

Central Statistics Office Ireland (2010), Population and Migration Estimates, April 2009

Cheung, S.Y., and A. Buchanan (1997), 'Malaise scores in adulthood of children and young people who have been in care', Journal of Child Psychology and Psychiatry, 38(5), pp. $575-580$

Chiuri, M.C. and D. Del Boca (2008), 'Household membership decisions of adult children’, IZA Discussion Paper No. 3546, June.

Clark, A.E. Georgellis, Y, and Sanfeym P. (2001), 'Scarring: the psychological impact of past unemployment', Economica, 68(270), pp. 221-241.

Clark, A.E. and A.J. Oswald (1994), 'Unhappiness and unemployment', Economic Journal, 104(424), pp. 648-659. 
Clark, D. (forthcoming), 'Do Recessions Keep Students in School? The Impact of Youth Unemployment on Enrolment in Post-Compulsory Education in England', Economica, [Published online 2009]

Clark, K.B. and L.H. Summers, L.H. (1982), 'The dynamics of youth unemployment' in Freeman, R. B. and D. A. Wise, (editors), The Youth Labor Market Problem: Its Nature, Causes, and Consequences, University of Chicago Press and NBER

Congressional Budget Office (2004) 'What is happening to youth employment rates", November.

Ellwood, D. (1982), 'Teenage unemployment: permanent scars or temporary blemishes?' in The Youth Labor Market Problem: Its Nature, Causes and Consequences, edited by Richard B. Freeman and David A. Wise, pp. 349-390. Chicago: University of Chicago Press.

Freeman, R.B., (1979) 'The Effect of Demographic Factors on Age Earnings Profiles', Journal of human resources, 14, No 3, pp. 289-318

Freeman, R.B. and J. Rogers, (2000), 'Area economic conditions and the labour market outcomes of young men in the 1990s expansion', in Cherry, R. and Rodgers, W. M. (editors), Prosperity for All: The Economic Boom and African Americans, Russell Sage Foundation, New York

Freeman, R.B. and Wise, D.A. (1982), 'The youth labor market problem: its nature causes and consequences:' in Freeman, R. B. and D. A. Wise, (editors), The Youth Labor Market Problem: Its Nature, Causes, and Consequences, University of Chicago Press and NBER.

Giuliano, P. and A. Spilimbergo (2009), 'Growing up in a recession: beliefs and the macroeconomy’, NBER Working Paper No. 15321, September.

Grubb, W.N. (1999), 'Lessons from education and training for youth: five precepts, in preparing youth for the 21st Century: the transition from education to the labour market', OECD, Paris.

Grubb, D. and J. Martin (2001) 'What works and for whom: a review of OECD countries' experiences with active labour market policies', OECD Office of Labour Market Policy Evaluation Working Paper 2001:14

Heckman, J.J. and J.A. Smith (1999a), 'The pre-programme earnings dip and the determinants of participation in a social programme. Implications for simple evaluation strategies', Economic Journal, July, 109, pp. 313-348.

Heckman, J.J. and J.A. Smith (1999b), 'The sensitivity of experimental impact estimates: evidence from the National JTPA Study' in Youth Employment and Joblessness in Advanced Countries, edited by David G. Blanchflower and Richard B. Freeman, University of Chicago Press and NBER, Chicago, Illinois. 
HM Treasury (2010) “Government announces £6.2bn of savings in 2010-11”, [Available at: http://www.hm-treasury.gov.uk/d/press_04_10.pdf. Accessed February 2011]

ILO (2008), 'Global employment trends for youth', October, ILO Geneva.

ILO (2011), Key Indicators of the Labour Market (KILM) [Available at http://www.ilo.org/empelm/what/lang--en/WCMS_114240, Accessed February 2011]

Kahn, L.B. (2010), 'The long-term labor market consequences of graduating from college in a bad economy’, Labour Economics, 17(2), April, pp. 303-316.

Knabe, A. and S. Ratzel, 'Scarring or Scaring? The psychological impact of past unemployment and future unemployment risk', Economica (forthcoming)

Knabe, A., S. Ratzel, R. Schob and J. Weimann, 'Dissatisfied with life but having a good day: Time-use and well-being of the unemployed', Economic Journal, (forthcoming)

Mercer, S. and Notley, R. (2008), Trade Union Membership, 2007, July, Department of Business, Enterprise and Regulatory Reform.

[Available at http://stats.berr.gov.uk/UKSA/tu/tum2008.pdf Accessed February 2011]

Mroz, T.A. and Savage, T.H. (2006), 'The long-term effects of youth unemployment', Journal of Human Resources, Spring, 41(2), pp. 259-293.

Metcalf, D., (2008) 'Why has the British National Minimum Wage had Little or No Impact on Employment?’, Journal of Industrial Relations 50: 489-512.

OECD (1994), The OECD Jobs Study: Facts, Analysis, Strategies, OECD, Paris

OECD (2008), 'Off to a good start? Youth labour market transitions in OECD countries', Paris.

OECD (2009) "Addressing the labour market challenges of the economic downturn: a summary of country responses to the OECD-EC questionnaire”, OECD, Paris [Available at http://www.oecd.org/dataoecd/15/29/43732441.pdf Accessed February 20011]

OECD (2010), "The role of labour market and social policy in promoting a job-rich recovery”, Speech by OECD Secretary-General, OECD, Paris [Available at http://www.oecd.org/document/54/0,3746,en_21571361_44315115_45029686_1_1_1_1, 00.html Accessed February 20011]

Oswald, A.J., E. Proto and D. Sgroi (2010), "Happiness and productivity", May, working paper.

Scarpetta, S., A. Sonnet and T. Manfredi (2010), 'Rising youth unemployment during the crisis: how to prevent negative long-term consequences on a generation?', OECD April. 
Van Reenen, J., (2004), "Active Labor Market policies and the British New Deal for the young unemployed in context" in: Seeking a Premier Economy: The Economic Effects of British Economic Reforms, 1980-2000, pages 461-496 National Bureau of Economic Research.

Welch, F., (1979) 'Effects of cohort size on earnings: the baby boom babies' financial bust ', Journal of Political Economy, 87, 5, PP. S65-S97

Winkelmann, L. and Winkelmann, R., (1998), 'Why are the unemployed so unhappy? Evidence from panel data', Economica, 65(257), pp. 1-15. 
Table 1: Youth Unemployment Rates 1970-2009 (Per Cent)

\begin{tabular}{|c|c|c|c|c|c|c|c|c|c|c|}
\hline & 1970-74 & $1975-79$ & 1980-84 & 1985-89 & 1990-94 & 1995-99 & 2000-04 & 2005-07 & 2008 & 2009 \\
\hline Australia & 3.4 & 11.3 & 14.6 & 13.9 & 17.1 & 15.0 & 12.3 & 10.0 & 8.9 & 11.6 \\
\hline Austria & & & & & 5.0 & 5.7 & 6.7 & 9.4 & 8.1 & 10.0 \\
\hline Belgium & & & 24.5 & 19.9 & 16.4 & 21.2 & 18.3 & 20.3 & 18.0 & 21.9 \\
\hline Canada & & 13.2 & 16.1 & 13.3 & 15.7 & 15.1 & 13.2 & 11.7 & 11.6 & 15.3 \\
\hline Denmark & & & 16.4 & 9.7 & 12.0 & 9.1 & 8.0 & 8.1 & 7.6 & 11.2 \\
\hline Finland & 4.3 & 10.5 & 10.2 & 9.2 & 22.1 & 23.5 & 19.7 & 17.4 & 15.7 & 20.5 \\
\hline France & 3.9 & 10.8 & 19.1 & 22.5 & 22.3 & 26.5 & 19.5 & 20.1 & 18.1 & 22.8 \\
\hline Germany & 1.2 & 5.1 & 8.3 & 7.4 & 6.4 & 9.1 & 9.9 & 13.5 & 10.4 & 11.0 \\
\hline Greece & & & 23.5 & 24.9 & 25.9 & 30.3 & 27.6 & 24.7 & 22.1 & 25.8 \\
\hline Ireland & 9.1 & 12.2 & 19.1 & 23.7 & 22.4 & 15.2 & 8.7 & 9.8 & 12.5 & 25.9 \\
\hline Italy & 11.4 & 20.3 & 28.5 & 34.4 & 30.8 & 31.9 & 26.6 & 22.0 & 21.3 & 25.4 \\
\hline Japan & 2.3 & 3.4 & 4.2 & 4.9 & 4.7 & 7.3 & 9.7 & 8.1 & 7.2 & 9.1 \\
\hline Korea & & & 9.9 & 8.1 & 7.6 & 10.0 & 10.0 & 9.7 & 9.3 & 9.8 \\
\hline Luxembourg & & & 6.1 & 5.1 & 4.4 & 7.4 & 9.5 & 15.0 & 17.9 & 17.2 \\
\hline Netherlands & 2.7 & 7.3 & 18.3 & 16.7 & 9.9 & 9.8 & 6.4 & 7.3 & 5.6 & 7.3 \\
\hline New Zealand & & & 0.0 & 0.1 & 17.2 & 13.5 & 11.5 & 9.9 & 11.4 & 16.6 \\
\hline Norway & 5.4 & 6.2 & 6.9 & 7.2 & 13.0 & 10.7 & 11.1 & 9.3 & 7.5 & 9.2 \\
\hline Portugal & 3.2 & 14.8 & 16.7 & 15.2 & 10.8 & 13.1 & 11.9 & 16.3 & 16.5 & 20.0 \\
\hline Spain & 4.9 & 12.8 & 34.0 & 39.2 & 35.1 & 35.9 & 22.6 & 18.6 & 24.6 & 37.9 \\
\hline Sweden & 4.7 & 5.2 & 8.3 & 5.5 & 14.3 & 18.6 & 13.5 & 20.9 & 19.4 & 25.0 \\
\hline United Kingdom & & & 19.7 & 14.9 & 14.5 & 13.6 & 11.1 & 13.5 & 14.1 & 18.9 \\
\hline United States & 11.6 & 13.7 & 15.5 & 12.2 & 12.9 & 11.1 & 11.2 & 10.8 & 12.8 & 17.6 \\
\hline Europe & 4.6 & 11.1 & 19.1 & 19.8 & 18.1 & 18.5 & 17.4 & 17.1 & 15.7 & 20.1 \\
\hline OECD countries & 5.1 & 10.4 & 15.2 & 15.3 & 15.3 & 15.6 & 14.6 & 14.5 & 13.2 & 20.9 \\
\hline
\end{tabular}

Sources: 1970-2009 OECD 
Table 2: Ratio of Unemployment Rates of those Aged 16-24 to Unemployment Rates of those Aged 25-64: 1970-2009

\begin{tabular}{|c|c|c|c|c|c|c|c|c|c|c|}
\hline & $1970-74$ & $1975-79$ & $1980-84$ & $1985-89$ & $1990-94$ & 1995-99 & $2000-04$ & $2005-07$ & 2008 & 2009 \\
\hline Australia & 2.25 & 3.26 & 2.85 & 2.52 & 2.28 & 2.37 & 2.59 & 2.76 & 2.73 & 2.86 \\
\hline Austria & & & & & 1.50 & 1.54 & 1.84 & 2.23 & 2.53 & 2.31 \\
\hline Belgium & & & 2.67 & 2.26 & 2.48 & 2.70 & 2.94 & 2.92 & 3.04 & 2.97 \\
\hline Canada & & 2.30 & 2.04 & 1.72 & 1.71 & 1.98 & 2.14 & 2.16 & 2.25 & 2.21 \\
\hline Denmark & & & 2.13 & 1.54 & 1.41 & 1.74 & 1.82 & 2.25 & 2.97 & 2.54 \\
\hline Finland & 2.33 & 2.64 & 2.42 & 2.37 & 2.41 & 2.08 & 2.60 & 2.74 & 3.18 & 2.85 \\
\hline France & 2.32 & 3.11 & 3.45 & 2.78 & 2.49 & 2.50 & 2.46 & 2.79 & 2.96 & 2.79 \\
\hline Germany & 1.16 & 1.50 & 1.60 & 1.23 & 0.94 & 1.02 & 1.14 & 1.34 & 1.43 & 1.40 \\
\hline Greece & & & 4.18 & 4.93 & 4.71 & 3.99 & 3.26 & 3.14 & 3.31 & 3.18 \\
\hline Ireland & 1.48 & 1.72 & 1.66 & 1.63 & 1.72 & 1.79 & 2.45 & 2.65 & 2.71 & 2.70 \\
\hline Italy & 7.50 & 7.72 & 7.12 & 5.29 & 4.33 & 3.69 & 3.65 & 3.80 & 3.77 & 4.06 \\
\hline Japan & 2.13 & 1.80 & 1.94 & 2.09 & 2.32 & 2.17 & 2.08 & 2.05 & 1.89 & 2.11 \\
\hline Korea & & & 3.12 & 3.35 & 4.37 & 2.97 & 3.09 & 3.06 & 3.22 & 2.95 \\
\hline Luxembourg & & & 3.01 & 3.13 & 2.41 & 3.30 & 3.71 & 4.28 & 4.42 & 4.65 \\
\hline Netherlands & 1.40 & 2.37 & 2.45 & 1.92 & 1.71 & 2.20 & 2.15 & 1.90 & 2.27 & 2.16 \\
\hline New Zealand & & & & 2.75 & 2.34 & 2.49 & 2.98 & 3.95 & 4.14 & 4.22 \\
\hline Norway & 7.12 & 5.99 & 3.99 & 3.62 & 3.00 & 3.59 & 3.84 & 3.35 & 4.23 & 4.13 \\
\hline Portugal & 5.79 & 4.33 & 3.86 & 3.13 & 2.69 & 2.49 & 2.60 & 2.24 & 2.30 & 2.18 \\
\hline Spain & 3.20 & 3.35 & 3.41 & 2.78 & 2.23 & 2.12 & 2.26 & 2.47 & 2.51 & 2.57 \\
\hline Sweden & 2.77 & 3.76 & 3.67 & 3.09 & 3.01 & 2.39 & 2.81 & 4.04 & 4.61 & 4.39 \\
\hline United Kingdom & & & 2.07 & 1.76 & 1.87 & 2.24 & 2.86 & 3.88 & 3.79 & 3.94 \\
\hline United States & 3.29 & 2.79 & 2.45 & 2.50 & 2.42 & 2.95 & 2.72 & 2.83 & 2.78 & 2.90 \\
\hline OECD & 3.0 & 3.1 & 3.0 & 2.6 & 2.4 & 2.4 & 2.6 & 2.7 & 2.8 & 3.1 \\
\hline
\end{tabular}

Source: OECD Stat Extracts: Labour Force Survey by sex and age 
Table 3: Youth and Adult Unemployment Rates 2008-2010 (Source: Eurostat)

\begin{tabular}{|c|c|c|c|c|c|c|c|c|c|c|}
\hline & \multicolumn{3}{|c|}{ Total } & \multicolumn{3}{|c|}{ Under 25} & \multicolumn{3}{|c|}{25 and over } & \multirow[t]{2}{*}{ Difference } \\
\hline & 2008 Q1 & $2010 \mathrm{Q} 4$ & Change & 2008 Q1 & 2010 Q4 & Change & 2008 Q1 & 2010 Q4 & Change & \\
\hline Germany & 7.6 & 6.6 & -1.0 & 10.2 & 8.5 & -1.7 & 7.2 & 6.3 & -0.9 & -0.8 \\
\hline Austria & 3.9 & 4.2 & 0.3 & 8.1 & 8.0 & -0.1 & 3.2 & 3.6 & 0.4 & -0.5 \\
\hline Luxembourg & 4.4 & 4.8 & 0.4 & 15.4 & 17.5 & 2.1 & 3.5 & 3.9 & 0.4 & 1.7 \\
\hline Netherlands & 3.1 & 4.4 & 1.3 & 6.2 & 8.3 & 2.1 & 2.5 & 3.6 & 1.1 & 1.0 \\
\hline Norway & 2.4 & 3.5 & 1.1 & 6.8 & 8.9 & 2.1 & 1.6 & 2.6 & 1.0 & 1.1 \\
\hline Turkey & 9.0 & 10.6 & 1.6 & 17.0 & 19.4 & 2.4 & 7.1 & 8.8 & 1.7 & 0.7 \\
\hline Belgium & 6.9 & 8.2 & 1.3 & 17.3 & 20.5 & 3.2 & 5.9 & 7.0 & 1.1 & 2.1 \\
\hline Romania & 5.7 & 7.3 & 1.6 & 18.5 & 21.7 & 3.2 & 4.3 & 5.8 & 1.5 & 1.7 \\
\hline Sweden & 5.9 & 7.9 & 2.0 & 19.0 & 23.6 & 4.6 & 3.9 & 5.5 & 1.6 & 3.0 \\
\hline Finland & 6.3 & 8.0 & 1.7 & 15.9 & 20.7 & 4.8 & 4.9 & 6.3 & 1.4 & 3.4 \\
\hline Slovenia & 4.7 & 7.6 & 2.9 & 11.2 & 16.1 & 4.9 & 3.9 & 6.8 & 2.9 & 2.0 \\
\hline United Kingdom & 5.1 & 7.7 & 2.6 & 13.8 & 19.1 & 5.3 & 3.6 & 5.8 & 2.2 & 3.1 \\
\hline European Union (27 countries) & 6.7 & 9.6 & 2.9 & 14.8 & 20.7 & 5.9 & 5.7 & 8.3 & 2.6 & 3.3 \\
\hline Portugal & 7.6 & 11.2 & 3.6 & 15.9 & 21.9 & 6.0 & 6.7 & 10.4 & 3.7 & 2.3 \\
\hline France & 7.6 & 9.7 & 2.1 & 18.0 & 24.4 & 6.4 & 6.4 & 8.0 & 1.6 & 4.8 \\
\hline Poland & 7.5 & 9.7 & 2.2 & 17.8 & 24.2 & 6.4 & 6.3 & 8.2 & 1.9 & 4.5 \\
\hline Denmark & 3.3 & 7.7 & 4.4 & 7.6 & 14.0 & 6.4 & 2.5 & 6.5 & 4.0 & 2.4 \\
\hline Italy & 6.5 & 8.4 & 1.9 & 20.8 & 27.3 & 6.5 & 5.3 & 7.0 & 1.7 & 4.8 \\
\hline United States & 5.0 & 9.6 & 4.6 & 11.5 & 18.3 & 6.8 & 3.9 & 8.2 & 4.3 & 2.5 \\
\hline Hungary & 7.5 & 11.5 & 4.0 & 19.6 & 27.7 & 8.1 & 6.6 & 10.3 & 3.7 & 4.4 \\
\hline Czech Republic & 4.4 & 7.4 & 3.0 & 10.0 & 18.3 & 8.3 & 3.9 & 6.5 & 2.6 & 5.7 \\
\hline Bulgaria & 6.1 & 10.1 & 4.0 & 13.7 & 23.2 & 9.5 & 5.4 & 8.9 & 3.5 & 6.0 \\
\hline Croatia & 8.8 & 12.9 & 4.1 & 22.6 & 32.5 & 9.9 & 7.2 & 10.2 & 3.0 & 6.9 \\
\hline Greece & 7.8 & 12.9 & 5.1 & 22.3 & 33.4 & 11.1 & 6.7 & 11.5 & 4.8 & 6.3 \\
\hline Cyprus & 3.7 & 7.2 & 3.5 & 9.1 & 20.4 & 11.3 & 3.1 & 5.8 & 2.7 & 8.6 \\
\hline Slovakia & 10.1 & 14.5 & 4.4 & 19.1 & 36.5 & 17.4 & 9.1 & 12.3 & 3.2 & 14.2 \\
\hline Ireland & 4.9 & 13.8 & 8.9 & 10.1 & 28.3 & 18.2 & 4.0 & 12.1 & 8.1 & 10.1 \\
\hline Estonia & 4.2 & 14.3 & 10.1 & 7.4 & 25.9 & 18.5 & 3.8 & 13.0 & 9.2 & 9.3 \\
\hline Spain & 9.2 & 20.5 & 11.3 & 20.8 & 43.0 & 22.2 & 7.8 & 18.4 & 10.6 & 11.6 \\
\hline Latvia & 6.1 & 18.3 & 12.2 & 10.9 & 33.3 & 22.4 & 5.4 & 16.3 & 10.9 & 11.5 \\
\hline Lithuania & 4.1 & 17.4 & 13.3 & 8.5 & 34.4 & 25.9 & 3.6 & 15.6 & 12.0 & 13.9 \\
\hline
\end{tabular}


Table 4. Probability of being unemployed, 2008-2010 (dprobit).

\begin{tabular}{|c|c|c|c|}
\hline & 2008 & 2009-2010 & 2008-2010 \\
\hline Male & $-.0279(10.66)$ & $-.0071(2.31)$ & -.0177 (8.77) \\
\hline Age $<25$ & .1159 (18.66) & $.1646(22.70)$ & $1229(19.30)$ \\
\hline Age 25-34 & $.0330(8.04)$ & .0450 (9.58) & .0389 (12.47) \\
\hline Age 45-54 & $.0097(2.56)$ & $.0046(1.05)$ & $.0071(2.46)$ \\
\hline Age 55-64 & $.0250(5.28)$ & .0065 (1.22) & $.0157(4.40)$ \\
\hline Age $\geq 65$ & $-.0395(4.26)$ & $-.0741(6.72)$ & -.0566 (7.89) \\
\hline 2009 & & $-.0089(2.76)$ & .0345 (13.77) \\
\hline 2010 & & & .0435 (13.51) \\
\hline Austria & $-.0553(8.22)$ & -.1035 (13.34) & $-.0785(15.24)$ \\
\hline Denmark & $-.0325(3.87)$ & $-.0241(2.24)$ & $-.0303(4.45)$ \\
\hline Finland & $-.0334(3.97)$ & $-.0306(2.88)$ & $-.0327(4.80)$ \\
\hline France & $-.0298(3.76)$ & $-.0375(3.76)$ & $-.0336(5.27)$ \\
\hline Germany & $-.0095(1.24)$ & $-.0190(2.04)$ & $-.0135(2.23)$ \\
\hline Greece & $-.0341(4.22)$ & $-.0576(5.98)$ & $-.0453(7.17)$ \\
\hline Ireland & $-.0484(6.65)$ & $-.0051(0.49)$ & $-.0297(4.68)$ \\
\hline Italy & $-.0546(8.02)$ & $-.0926(11.16)$ & $-.0727(13.51)$ \\
\hline Luxembourg & $-.0605(6.48)$ & $-.0655(5.37)$ & $-.0640(8.35)$ \\
\hline Netherlands & $-.0536(6.98)$ & $-.0620(6.38)$ & $-.0583(9.40)$ \\
\hline Portugal & $-.0313(4.16)$ & $-.0388(4.10)$ & $-.0350(5.78)$ \\
\hline Spain & $-.0056(0.65)$ & $.0327(2.94)$ & .0133 (1.88) \\
\hline Sweden & $-.0549(7.34)$ & $-.0573(5.73)$ & $-.0574(9.24)$ \\
\hline UK & $-.0178(2.27)$ & $-.0162(1.65)$ & $-.0168(2.66)$ \\
\hline Cyprus & $-.0647(7.21)$ & $-.0701(6.08)$ & $-.0683(9.35)$ \\
\hline Czech Republic & $-.0454(6.33)$ & $-.0563(6.21)$ & $-.0509(8.80)$ \\
\hline Estonia & $-.0579(7.87)$ & $.0045(0.42)$ & $-.0294(4.51)$ \\
\hline Hungary & $.0186(1.98)$ & $.0291(2.54)$ & $.0241(3.25)$ \\
\hline Latvia & $.0014(0.17)$ & $.0720(6.20)$ & .0351 (4.87) \\
\hline Lithuania & $.0102(1.15)$ & .0677 (5.69) & $.0376(5.05)$ \\
\hline Malta & $-.0449(4.16)$ & $-.0572(4.27)$ & -.0512 (5.93) \\
\hline Poland & $.0283(2.92)$ & $.0016(0.15)$ & .0165 (2.23) \\
\hline Slovakia & $-.0379(5.22)$ & $-.0393(4.24)$ & $-.0387(6.56)$ \\
\hline Slovenia & $-.0051(0.57)$ & -.0168 (1.59) & -.0109 (1.58) \\
\hline Bulgaria & $.0209(2.32)$ & .0262 (2.39) & $.0245(3.42)$ \\
\hline Romania & $-.0180(2.20)$ & $-.0340(3.38)$ & $-.0255(3.92)$ \\
\hline ALS 16-19 & $-.0496(13.21)$ & $-.0660(13.82)$ & -.0577 (19.08) \\
\hline ALS 20+ & $-.0944(24.68)$ & $-.1263(26.39)$ & $-.1100(36.01)$ \\
\hline No FT education & $.0825(2.94)$ & $-.0045(0.21)$ & $.0300(1.80)$ \\
\hline Age $<25 * 2009$ & & & .0151 (2.09) \\
\hline Age $<25 * 2010$ & & & .0298 (3.12) \\
\hline $\mathrm{N}$ & 44,354 & 44,215 & 88,569 \\
\hline Adjusted $\mathrm{R}^{2}$ & .0734 & .0781 & .0759 \\
\hline
\end{tabular}

Source: Eurobarometers \#69.1 (February-March 2008); \#69-2 (March-May 2008); \#70.1 (October-November 2008); \#72.1 (August-September-October 2009); \#72.2 (September-October 2009); and \#73.1 (JanuaryFebruary 2010). Notes; sample consists of the labour force (employed+unemployed). Excluded categories Belgium and ALS<age 15. T-statistics in parentheses. 
Table 5. Youth Unemployment and Educational Attainment

\begin{tabular}{|l|c|c|c|c|c|c|c|c|c|}
\hline & \multicolumn{3}{|c|}{ ISCED 1-2 } & \multicolumn{3}{c|}{ ISCED 3-4 } & \multicolumn{3}{c|}{ ISCED 5-6 } \\
\hline & $2008 \mathrm{Q} 1$ & $2010 \mathrm{Q} 1$ & Change & $2008 \mathrm{Q} 1$ & $2010 \mathrm{Q} 1$ & Change & 2008Q1 & 2010Q1 & Change \\
\hline European Union & 20.1 & 27.6 & 7.5 & 12.6 & 18.9 & 6.3 & 9.7 & 15.1 & 5.4 \\
\hline Belgium & 30.7 & 39.6 & 8.9 & 13.1 & 23.7 & 10.6 & 9.2 & 11.6 & 2.4 \\
\hline Denmark & 8.1 & 15.7 & 7.6 & 5.3 & 11.4 & 6.1 & & & \\
\hline Ireland & 12.8 & 13.9 & 1.1 & 8.8 & 9.1 & 0.3 & & & \\
\hline Greece & 17.7 & 42.6 & 24.9 & 8 & 25 & 17 & 4.4 & 16.3 & 11.9 \\
\hline Spain & 19.3 & 27.6 & 8.3 & 25.3 & 29.9 & 4.6 & 26 & 41.8 & 15.8 \\
\hline France & 25.8 & 49 & 23.2 & 16.7 & 32.6 & 15.9 & 13.2 & 27.4 & 14.2 \\
\hline Italy & 28.4 & 34.5 & 6.1 & 15.2 & 21.5 & 6.3 & 7.9 & 12.4 & 4.5 \\
\hline Netherlands & 23.3 & 32.2 & 8.9 & 19.9 & 27.3 & 7.4 & 24.2 & 20.4 & -3.8 \\
\hline Austria & 7.9 & 11.1 & 3.2 & 3.9 & 6.6 & 2.7 & 0 & 4.5 & 4.5 \\
\hline Poland & 13.2 & 12 & -1.2 & 5 & 8 & 3 & & & \\
\hline Portugal & 22.7 & 34.4 & 11.7 & 19 & 23.7 & 4.7 & 14.1 & 20.9 & 6.8 \\
\hline Finland & 16.2 & 23.2 & 7 & 14.2 & 21 & 6.8 & 24.5 & 25.3 & 0.8 \\
\hline Sweden & 27.5 & 34 & 6.5 & 12.6 & 20.4 & 7.8 & & & \\
\hline United Kingdom & 25.1 & 44.8 & 9.7 & 13.3 & 23 & 9.7 & 13 & 19.3 & 6.3 \\
\hline
\end{tabular}

Source: Eurostat

Notes: International Standard Classification of Education (ISCED) levels are as follows: ISCED 0: pre-primary education; ISCED 1: primary education. ISCED 2; lower-secondary education; ISCED 3; upper-secondary education; ISCED 4: post-secondary non-tertiary level of education; ISCED 5: tertiary education: ISCED 6: second stage of tertiary education. Data for Denmark, Spain and Portugal relate to the $2^{\text {nd }}$ quarter of 2010 . 
Table 6 - Percent Change in Employment by Age Group 2008Q1 to 2010Q3

\begin{tabular}{|l|c|c|c|}
\hline Country\Age Group & $15-24$ & $25-49$ & $50-74$ \\
\hline Ireland & $-42 \%$ & $-11 \%$ & $-2 \%$ \\
\hline Latvia & $-34 \%$ & $-10 \%$ & $-20 \%$ \\
\hline Spain & $-32 \%$ & $-10 \%$ & $3 \%$ \\
\hline Slovakia & $-29 \%$ & $-2 \%$ & $8 \%$ \\
\hline Lithuania & $-28 \%$ & $-10 \%$ & $-4 \%$ \\
\hline Estonia & $-27 \%$ & $-8 \%$ & $-14 \%$ \\
\hline Portugal & $-25 \%$ & $-4 \%$ & $0 \%$ \\
\hline Italy & $-15 \%$ & $-4 \%$ & $8 \%$ \\
\hline Greece & $-14 \%$ & $-4 \%$ & $5 \%$ \\
\hline Euro area (17 countries) & $-10 \%$ & $-4 \%$ & $8 \%$ \\
\hline Bulgaria & $-9 \%$ & $-5 \%$ & $-6 \%$ \\
\hline Cyprus & $-8 \%$ & $0 \%$ & $8 \%$ \\
\hline European Union & $-8 \%$ & $-3 \%$ & $7 \%$ \\
\hline Hungary & $-8 \%$ & $-2 \%$ & $4 \%$ \\
\hline Czech Republic & $-7 \%$ & $1 \%$ & $-3 \%$ \\
\hline Germany & $-6 \%$ & $-1 \%$ & $12 \%$ \\
\hline United Kingdom & $-5 \%$ & $-1 \%$ & $3 \%$ \\
\hline Poland & $-5 \%$ & $2 \%$ & $16 \%$ \\
\hline Netherlands & $-4 \%$ & $-4 \%$ & $7 \%$ \\
\hline Norway & $-3 \%$ & $0 \%$ & $4 \%$ \\
\hline Belgium & $-1 \%$ & $-2 \%$ & $11 \%$ \\
\hline Slovenia & $-1 \%$ & $-4 \%$ & $11 \%$ \\
\hline Denmark & $1 \%$ & $-5 \%$ & $-1 \%$ \\
\hline France & $2 \%$ & $-2 \%$ & $8 \%$ \\
\hline Romania & $2 \%$ & $3 \%$ & $7 \%$ \\
\hline Austria & $2 \%$ & $1 \%$ & $12 \%$ \\
\hline Iceland & $2 \%$ & $-8 \%$ & $3 \%$ \\
\hline Malta & $3 \%$ & $2 \%$ & $13 \%$ \\
\hline Croatia & $10 \%$ & $-12 \%$ & $11 \%$ \\
\hline Finland & $12 \%$ & $-3 \%$ & $3 \%$ \\
\hline Luxembourg & $16 \%$ & $9 \%$ & $20 \%$ \\
\hline Sweden & $17 \%$ & $1 \%$ & $1 \%$ \\
\hline & & & \\
\hline
\end{tabular}

Source: Eurostat 
Table 7. Well-being in 2008/2009 at age 50

\begin{tabular}{|c|c|c|c|c|}
\hline & Life satisfaction & Health status & Down \& depressed & Job satisfaction \\
\hline Male & $-.2940(6.42)$ & $-.2264(4.56)$ & $.0023(0.22)$ & $-.2292(4.86)$ \\
\hline Other Scottish & $-.1626(2.31)$ & $-.0348(0.46)$ & $.0072(0.46)$ & $-.1155(1.39)$ \\
\hline GCSE a-c & $-.1704(2.86)$ & $.1841(2.86)$ & $.0230(1.72)$ & $-.1947(2.77)$ \\
\hline Intermediate $2 \mathrm{AS} / 1 \mathrm{~A}$ level & $-.7833(2.85)$ & $-.0377(0.13)$ & $.1086(1.59)$ & $-.3439(1.07)$ \\
\hline$\geq 2$ A levels & $-.2581(3.04)$ & $.4003(4.34)$ & $.0243(1.22)$ & $-.0485(0.51)$ \\
\hline Diploma & $-.2495(2.40)$ & $.2292(2.05)$ & $.0722(2.87)$ & $-.1413(1.17)$ \\
\hline Degree, PGCE, etc. & $-.1265(1.77)$ & $.4533(5.83)$ & $.0176(1.06)$ & $-.0798(0.98)$ \\
\hline Higher degree & $-.1010(0.87)$ & $.5772(4.50)$ & $.0358(1.24)$ & $.0718(0.56)$ \\
\hline Months unemployed $\leq$ age 23 & $-.0089(2.69)$ & $-.0074(2.00)$ & $.0017(2.52)$ & $-.0134(3.25)$ \\
\hline Malaise score@ age 23 & $-.1080(14.34)$ & $-.1252(15.04)$ & $.0293(18.47)$ & $-.0414(4.55)$ \\
\hline Very secure job & & & & $1.4708(18.87)$ \\
\hline Fairly secure job & & & & $.8303(11.35)$ \\
\hline Part-time paid employee & $-.2018(3.34)$ & $-.1252(1.92)$ & $.0524(3.70)$ & \\
\hline Full-time self-employed & $-.0220(0.34)$ & $.0656(0.94)$ & $.0048(0.32)$ & \\
\hline Part-time self-employed & $-.0150(0.12)$ & $-.1334(0.96)$ & $.0693(2.23)$ & \\
\hline Unemployed and seeking work & $\mathrm{k}-.7449(5.52)$ & $-.8653(6.00)$ & $.2298(6.71)$ & \\
\hline Full-time education & $6058(1.19)$ & $.3116(0.54)$ & $-.0747(0.64)$ & \\
\hline Government scheme & $-.3029(0.25)$ & $-.7341(0.61)$ & $.2955(0.84)$ & \\
\hline Temporarily sick/disabled & $-1.3095(4.62)$ & $-2.9032(9.04$ & $.3398(4.63)$ & \\
\hline Permanently sick/disabled & $-1.4056(13.98)$ & $-3.2894(26.62)$ & $.3951(14.39)$ & \\
\hline Looking after home/family & $-.2711(2.87)$ & $-.6154(5.92)$ & $.0984(4.33)$ & \\
\hline Wholly retired & $-.2427(1.01)$ & $-.6652(2.41)$ & $.0295(0.52)$ & \\
\hline Other LF & $-.1058(0.60)$ & $-.3595(1.89)$ & $.0469(1.14)$ & \\
\hline Married & $.8647(12.96)$ & $.1474(2.02)$ & $-.0502(3.35)$ & \\
\hline Civil partner & $.2699(0.57)$ & $-.2765(0.50)$ & $.1186(1.04)$ & \\
\hline Separated & $-.0630(0.50)$ & $.1500(1.09)$ & $.0174(0.64)$ & \\
\hline Divorced & $.2387(3.00)$ & $.0703(0.81)$ & $.0076(0.44)$ & \\
\hline Widowed & $-.5383(2.99)$ & $-.1741(0.88)$ & $.1547(3.52)$ & \\
\hline Used to smoke & $-.0399(0.88)$ & $-.1454(2.95)$ & $.0061(0.58)$ & \\
\hline
\end{tabular}




\begin{tabular}{|c|c|c|c|c|}
\hline Smokes occasionally & $-.1468(1.30)$ & $-.1811(1.50)$ & $.0178(0.69)$ & \\
\hline Smokes every day & $-.2645(4.66)$ & $-.4707(7.68)$ & $.0157(1.24)$ & \\
\hline No exercise & $-.2172(3.68)$ & $-.6371(9.88)$ & $.0525(3.84)$ & \\
\hline 4-5 days/week & $.1608(2.18)$ & $.1886(2.36)$ & $-.0051(0.30)$ & \\
\hline 2-3 days/week & $-.0186(0.32)$ & $-.0934(1.47)$ & $.0132(0.96)$ & \\
\hline Exercises once a week & $.0333(0.51)$ & $-.1629(2.31)$ & $.0172(1.12)$ & \\
\hline Exercises 2-3 times/month & $.1175(1.26)$ & $-.2754(2.72)$ & $.0065(0.30)$ & \\
\hline Exercises less often & $-.0755(0.49)$ & $-.4838(2.92)$ & $.0016(0.04)$ & \\
\hline Birth weight (ozs) & $.0028(2.63)$ & $.0019(1.66)$ & $-.0001(0.32)$ & \\
\hline Constant/Cut1 & 7.0740 & -3.9970 & & -3.4968 \\
\hline Cut2 & & -2.1815 & & -1.9132 \\
\hline Cut3 & & -.4561 & & -.8504 \\
\hline Cut4 & & 1.2212 & & 1.0683 \\
\hline Adjusted/Pseudo $\mathrm{R}^{2}$ & .1383 & .0904 & .1348 .0296 & \\
\hline $\mathrm{N}$ & 7535 & 7603 & 7535 & 7081 \\
\hline
\end{tabular}

Source: National Child Development Study, 1958-2009

Notes: excluded categories: no qualifications, full-time paid employee; single; never smoked and exercises every day. All equations also include 10 region dummies plus a 2009 dummy.

Dependent variables

Column 1. How satisfied are you with the way your life has turned out so far? Range 0-10; mean=7.29; SD=1.85 - estimated as OLS Column 2. Self-assessment of health 1=poor (5.7); 2=fair (12.7); 3=good (29.2); 4=very good (33.0); 5=excellent (19.4) - estimated as an ordered logit. Mean=3.48: $\mathrm{SD}=.95$.

Column 3. Respondent reports often being miserable and depressed (1,0 dummy) - mean=.19; $\mathrm{SD}=.39$ - estimated as a dprobit Column 4. Degree of satisfaction with current job; 1=very dissatisfied (1.7); 2= dissatisfied (5.8); 3=neither(11.2); 4=satisfied (39.8) and $5=$ very satisfied (41.5) mean $=4.14 ; \mathrm{SD}=3.48$

The coefficients provide estimates of marginal effects, that is the change in the probability for an infinitesimal change in each independent, continuous variable and the discrete change in the probability for dummy variables. 
Figure 1: Youth Time Dummies 1971-2009

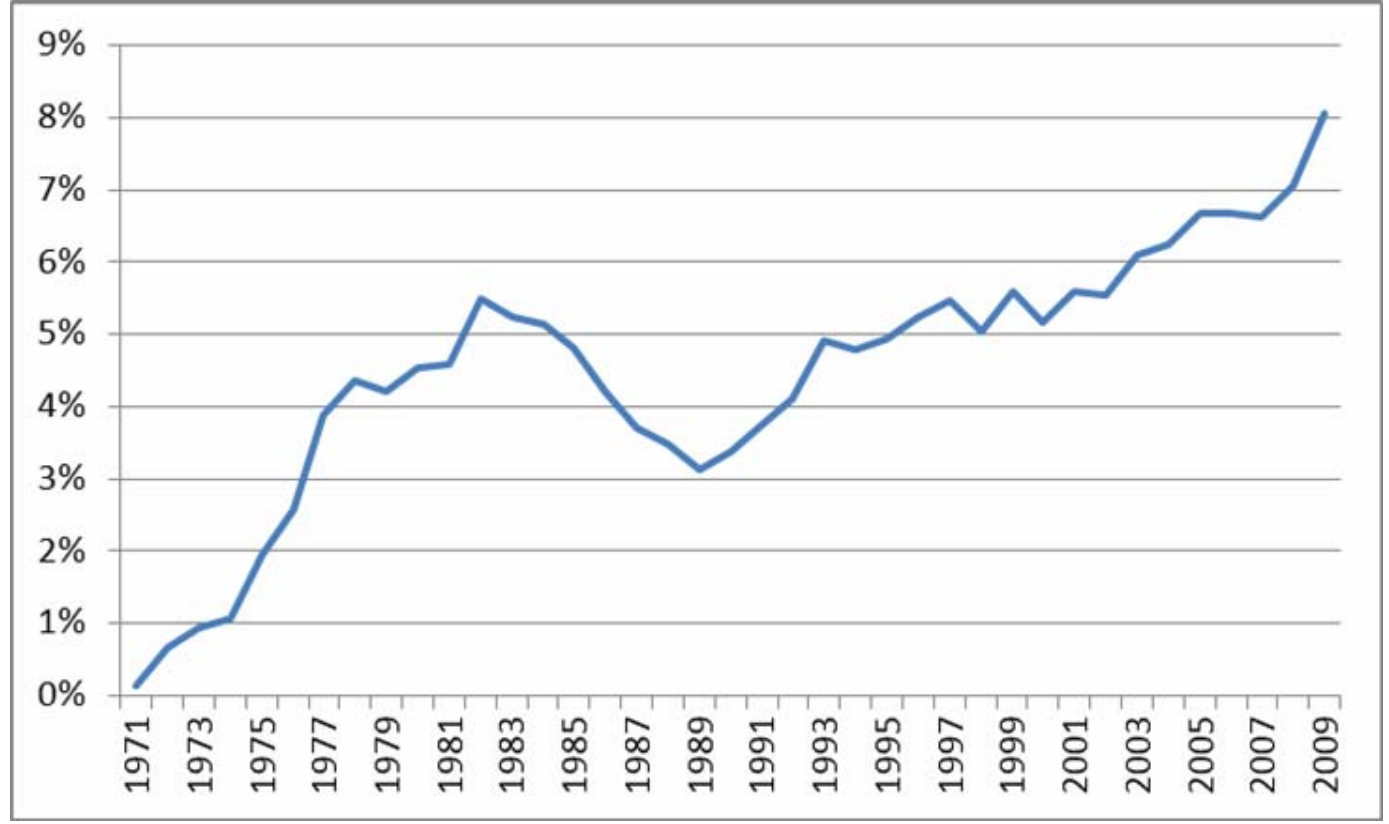

Figure 2: Country Youth Dummies

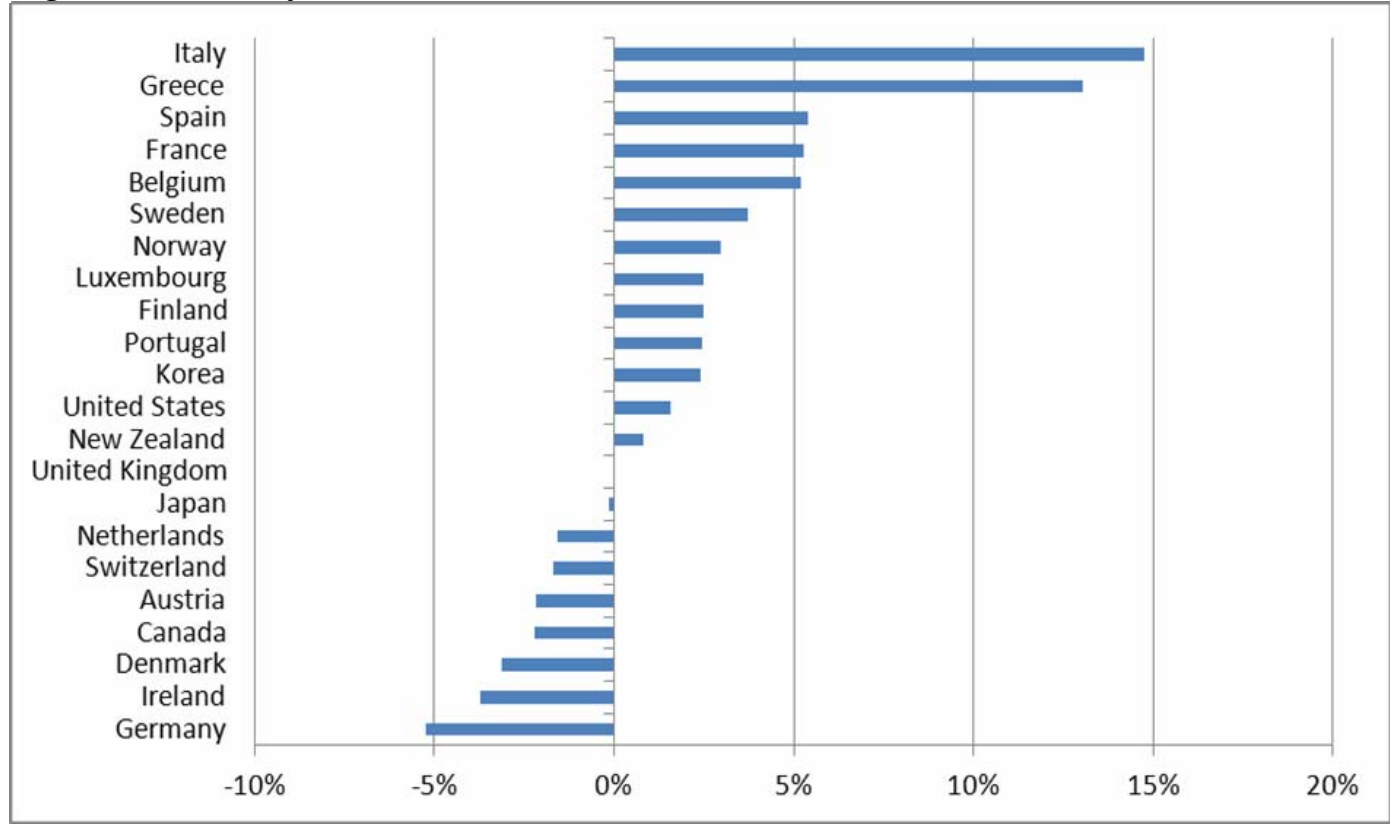

Notes:

1 Countries included - Australia, Austria, Belgium, Canada, Denmark, Finland, France, Germany, Greece, Ireland, Italy, Japan, Korea, Portugal, Spain, Sweden, Switzerland, United Kingdom and United States.

2 OLS Regression, $\mathrm{N}=860, \mathrm{~F}(39,797)=92.02$. Coefficient on adult rate $=1.87, t$ statistic $=45.8$. Omitted time dummy $=1970$. Omitted country dummy $=$ Australia 
Figure 3: Ratio of Median Youth to Median Adult Wages UK and USA 1997-2010

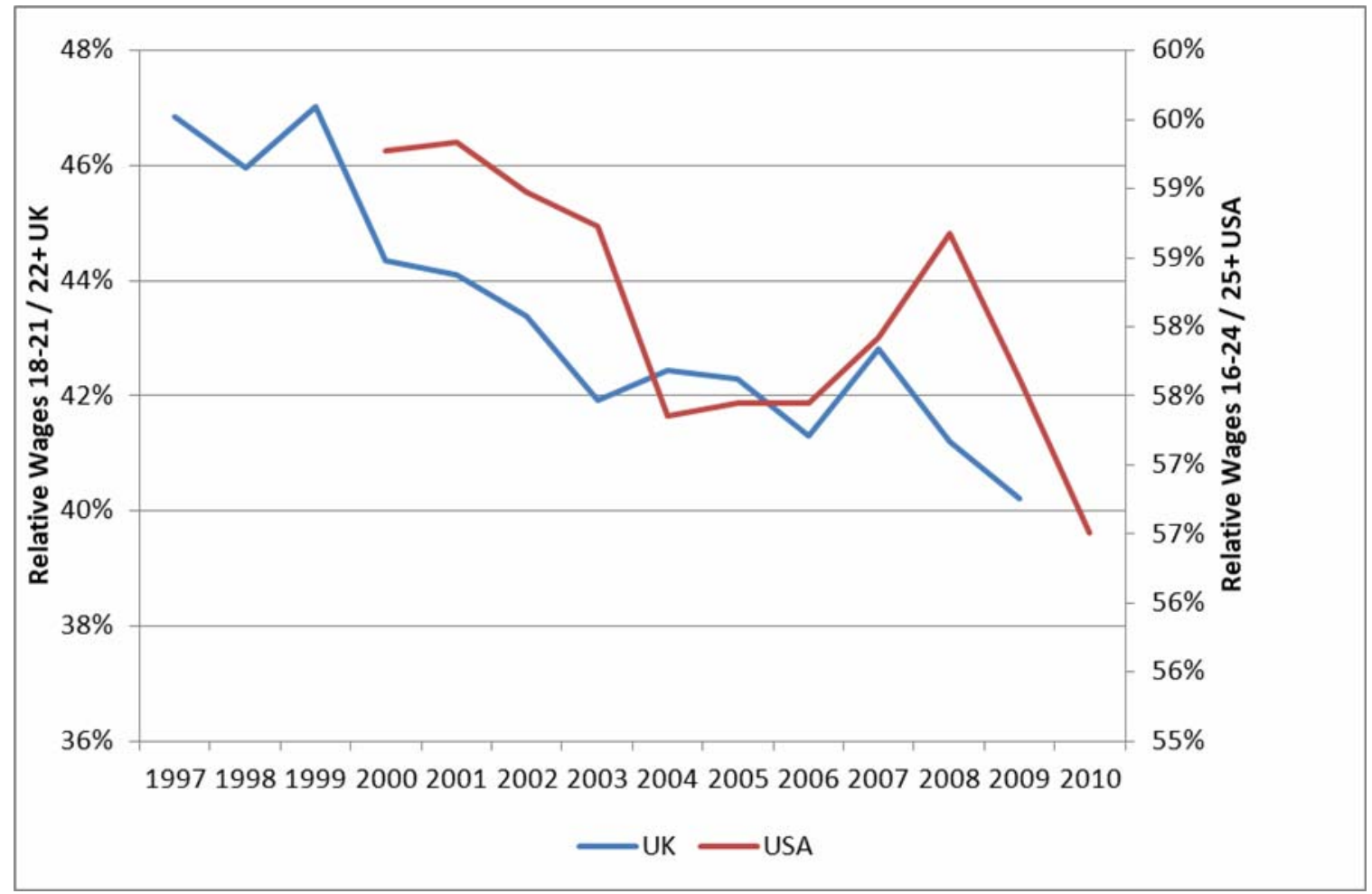

Source: ONS and BLS

Notes:

UK data from the Annual Survey of Hours and Earnings supplied by the Office of National Statistics. Ratio shown is median earnings of 18 to 21-year-olds divided by median earnings of 25 to 49 -year-olds.

US data from the Current Population Survey supplied by the Bureau of Labor Statistics. Ratio shown is median earnings of 16-24 year olds divided by median earnings of those aged 25 and above. 